$\frac{103}{3=18196}=(02)$

MLM-3818

EGE G

MOUND APPLIED TECHNOLOGIES

Design Development and Testing of 60-Watt Capsules

Joseph D. Ruhkamp

September 27, 1995

\title{
MOUND
}

is operated for the

U. S. Department of Energy

under contract No. DE-AC04-88-DP43495

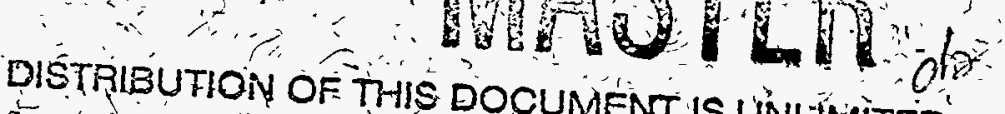

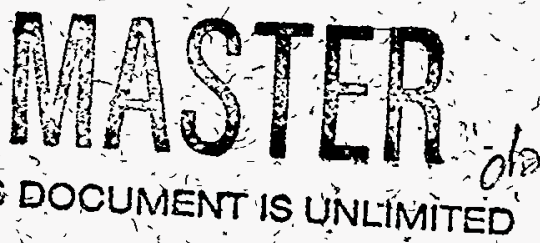




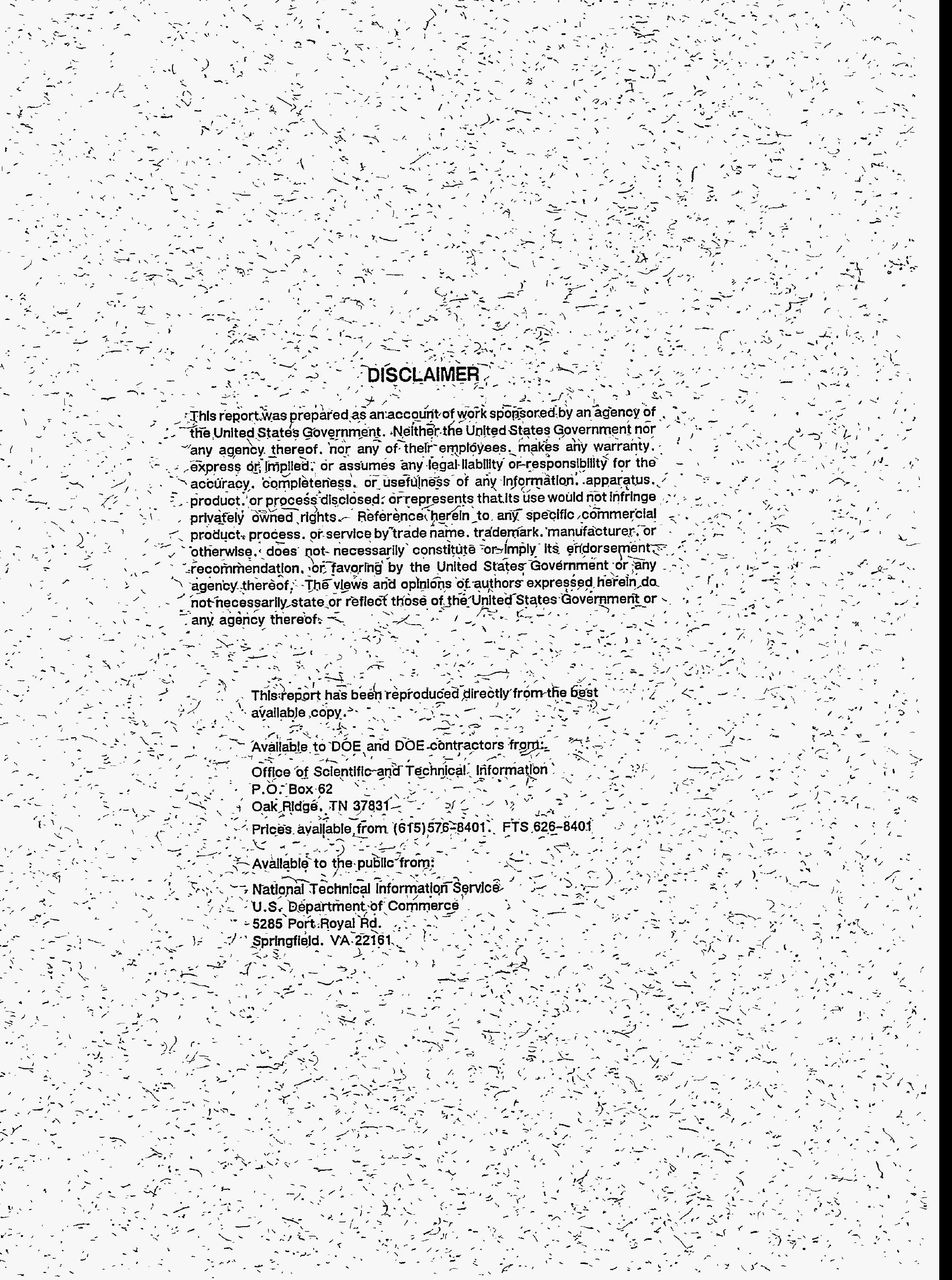


MLM-3818

UC-704

\section{Design Development and Testing of 60-Watt Capsules}

Joseph D. Ruhkamp

Issued: September 27, 1995

\section{MOUND}

operated by

EGRL MOUND APPLIED TECHNOLOGIES

P.O. Box 3000, Miamisburg, Ohio 45343-3000

for the

U. S. DEPARTMENT OF ENERGY

Contract No. DE-AC04-88DP43495 


\section{Table of Contents}

\section{page}

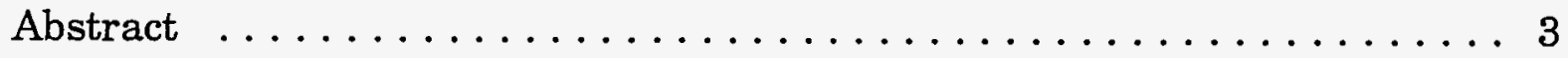

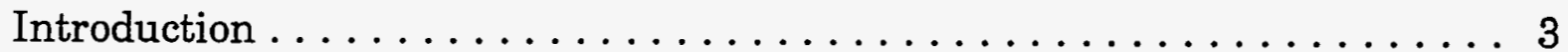

Weld Design Development Testing . . . . . . . . . . . . . . . 4

End Cap Design $\ldots \ldots \ldots \ldots \ldots \ldots \ldots \ldots \ldots \ldots \ldots \ldots \ldots \ldots \ldots \ldots \ldots$

Girth Weld Design $\ldots \ldots \ldots \ldots \ldots \ldots \ldots \ldots \ldots \ldots \ldots \ldots \ldots \ldots \ldots \ldots \ldots$

Girth Weld Testing . . . . . . . . . . . . . . . . . . 6

Test of Capsule PB5 . . . . . . . . . . . . . . . . . 7

Test of Capsule PB4 $\ldots \ldots \ldots \ldots \ldots \ldots \ldots \ldots \ldots \ldots \ldots \ldots \ldots$

Test of Capsules PB6, PB7, PB8, and PB9 . . . . . . . . . . . . . 9

Evaluation of ORNL Regression Model $\ldots \ldots \ldots \ldots \ldots \ldots \ldots$

Conclusions ............................. 11

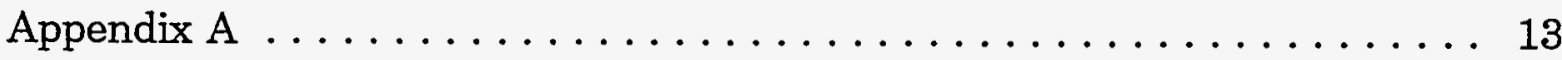

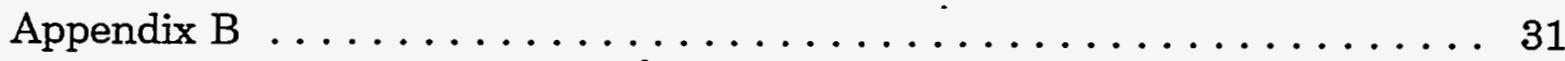

Distribution .......................... 35 


\section{Abstract}

To satisfy the safety requirements of a terrestrial 60-watt radioisotope heat source, it was necessary to determine whether the internal pressure buildup from the helium generated from $\mathrm{Pu}-238$ decay would pose problems in a fire environment. Nine strength members (capsules), three of the end-cap weld design and six of the girth weld design, were pressure-burst tested. The end-cap weld design was not successful, with failure times of less than three minutes. The girth weld design gave favorable results, with life times ranging from 8 to 240 hours. All of the girth weld capsules failed in the center of the weld. The Oak Ridge National Laboratory stress rupture model equation for determining test life does not predict the test hours to failure for the girth weld design.

\section{Introduction}

The object of these tests was to determine the creep rupture properties of the 60-watt strength member and to confirm the Teledyne Brown model of rupture time as a function of stress and temperature for T-111 alloy. The test capsules were pressurized with helium at room temperature and heated to test temperature in a vacuum furnace. Time, temperature; capsule pressure, furnace vacuum, and helium partial pressure were the parameters monitored until capsule failure.

There were two strength member designs, end-cap weld and girth weld. The first three tests, which were unsuccessful, were of capsules with the end-cap weld design. The remaining six tests, which gave favorable results, were of the girth weld design.

During the first tests it was determined that the ideal gas law was not appropriate for use in this pressure system. Since the gas in this system is not at constant temperature, an equation for a polytropic process was used to determine the starting pressure for each test. A discussion in Appendix A covers this approach. 


\section{Weld Design Development Testing}

\section{End Cap Design}

The first design tested was of the end cap configuration, shown in Figure 1. The results of the first three tests are given in Table 1.

Both of the gas tungsten arc (GTA) welds PB1 and PB2 failed in a similar manner. The weld overlap area had a crack that was intergranular in nature. Figure 2 shows a cross section of the weld joint and crack for PB1. Figure 3 is an external view of the cap showing a circumferential crack.

The GTA welds of PB1 and PB2 had large grains in the welded areas. The third capsule was

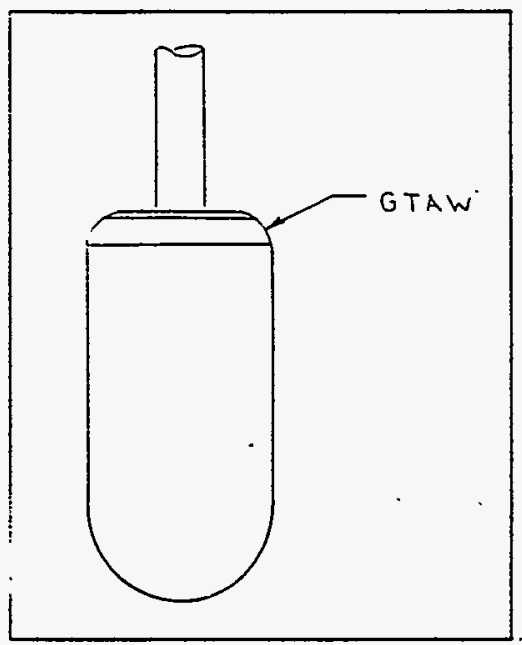

Figure 1 - End cap weld design. electron beam welded to reduce the grain size. The failure mode for the PB3 test was complete separation of capsule body from the cap. The failure of PB3 appeared intergranular in nature. The grain size in the electron beam (EB) welded area appears smaller than the grain size in the GTA welds. There was a small area without complete weld penetration, probably a result of not optimizing the joint for EB welding.

A calculation of the tangential stresses at the intersection of cap and cylinder .wall are presented in Table 2 (see Appendix B for equations). By interpolation of the data in Table 13 from NASA report CR-72859, Investigation of High

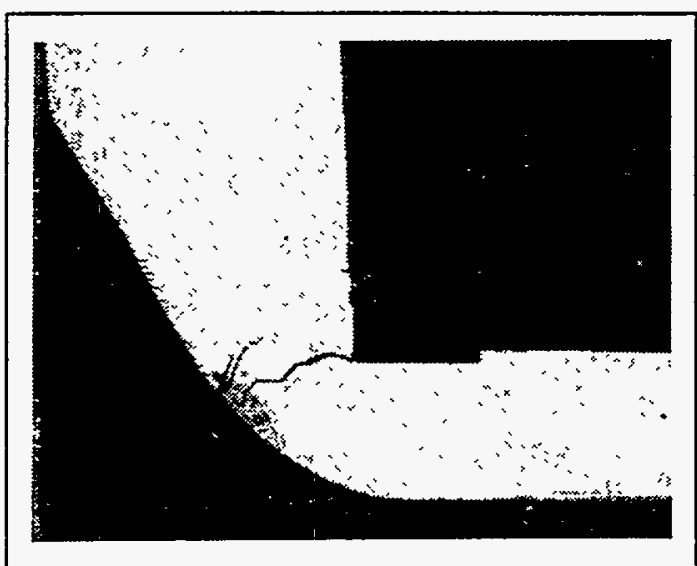

Figure 2 - Cross section shows cracked weld joint of end cap design (5X).

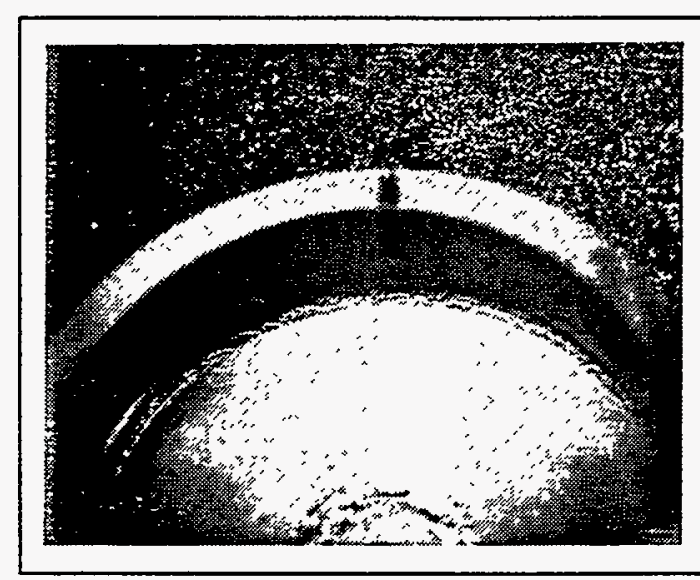

Figure 3 - Circumferential crack in weld joint of end cap design $(4 \mathrm{X})$. 
Temperature Fracture of T-111 and ASTAR-811C, it can be stated that at $1171^{\circ} \mathrm{C}$ the ultimate tensile strength for T-111 is $40,500 \mathrm{psi}$ and the yield strength is $24,900 \mathrm{psi}$. These values predict that the end cap design should fail.

\begin{tabular}{||c|c|c|c|c||}
\hline \multicolumn{5}{|c|}{ Table 1 - TEST RESULTS FOR END CAP WELD } \\
\hline $\begin{array}{c}\text { Capsule } \\
\text { Number }\end{array}$ & $\begin{array}{c}\text { Type of } \\
\text { Weld }\end{array}$ & $\begin{array}{c}\text { Temperature } \\
\left({ }^{\circ} \mathrm{C}\right)\end{array}$ & $\begin{array}{c}\text { Pressure } \\
\text { psig }\end{array}$ & $\begin{array}{c}\text { Failure Time } \\
\text { Minutes }\end{array}$ \\
\hline PB1 & GTA & 1171 & 4585 & 2 \\
\hline PB2 & GTA & 1171 & 4575 & 3 \\
\hline PB3 & EB & 1171 & 4395 & 2 \\
\hline
\end{tabular}

\begin{tabular}{||c|c|c|c|c|}
\hline \multicolumn{5}{|c|}{ Table 2 - TANGENTIAL STRESSES } \\
\hline $\begin{array}{c}\text { Temperature } \\
{ }^{\circ} \mathrm{C} \\
\cdot\end{array}$ & $\begin{array}{c}\text { Pressure } \\
\mathrm{psig}\end{array}$ & \multicolumn{3}{|c|}{ Stress (psi) } \\
\cline { 3 - 5 } & & Cylinder & Plate & Total \\
\hline 500 & 2700 & 18600 & 6290 & 24890 \\
\hline 600 & 3100 & 21400 & 7220 & 28620 \\
\hline 1171 & 4500 & 31000 & 10480 & 41480 \\
\hline
\end{tabular}

\section{Girth Weld Design}

A stress reduction of $25 \%$, not accounting for stress concentration, can be obtained by eliminating the tangential stress caused by the cap. This was accomplished by moving the weld joint to the capsule cylindrical wall, thereby eliminating the tangential stress and reducing the stress concentration. (Figure 4).

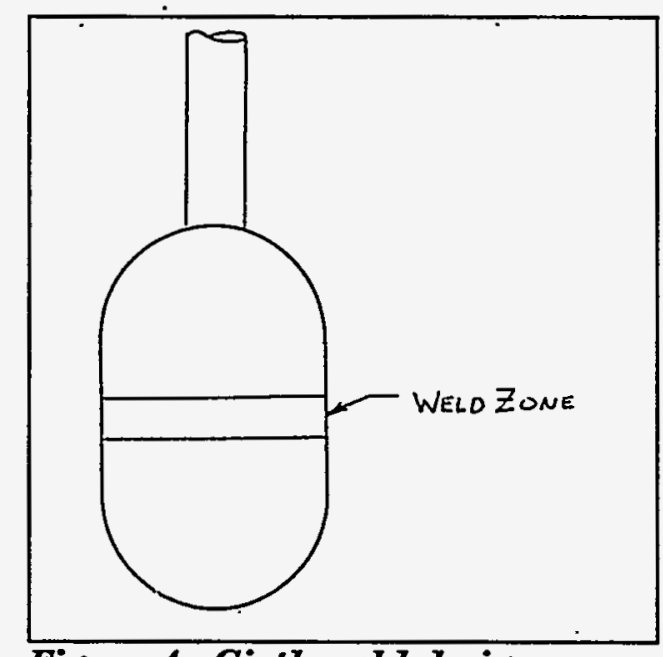

Figure 4 - Girth weld design. 


\section{Girth Weld Testing}

Six tests were conducted using the procedures from Mound Technical Manual MD-22139, 60 Watt Pressure Burst Test Procedures. The Oak Ridge National Laboratory (ORNL) regression model for stress rupture life, Equation 1, was used to predict failure time.

$$
\ln (t)=a+b * \ln (\operatorname{sig})+c * T
$$

where:

$$
\begin{array}{ll}
t & =\text { predicted life (hours) } \\
\mathrm{sig} & =\text { maximum stress }(7.3 * \text { pressure })(\mathrm{psi}) \\
\mathrm{T} & =\text { temperature }\left({ }^{\circ} \mathrm{R}\right) \\
\mathrm{a} & =84.34 \\
\mathrm{~b} & =-5.272 \\
\mathrm{c} & =-1.006 \times 10^{-2}
\end{array}
$$

Table 3 gives the test parameters, the life (failure time) from Teledyne Brown, and the ORNL equation. Table 4 gives the results of the development pressure burst tests.

\begin{tabular}{||c|c|c|c|c||}
\hline \multicolumn{5}{|c||}{ Table 3 - TEST MATRIX FROM TELEDYNE BROWN } \\
\hline $\begin{array}{c}\text { Temperature } \\
{ }^{\circ} \mathrm{C}\end{array}$ & $\begin{array}{c}\text { Pressure } \\
\text { psia }\end{array}$ & $\begin{array}{c}\text { Life } \\
\text { hours }\end{array}$ & $\begin{array}{c}\text { Capsule } \\
\text { Number }\end{array}$ & $\begin{array}{c}\text { ORNL } \\
\text { Equation }\end{array}$ \\
\hline 1000 & 6300 & 107 & PB8 & 107 \\
\hline 1000 & 6900 & 62 & PB9 & 66 \\
\hline 1171 & 3800 & $*$ & PB4 & 69 \\
\hline 1171 & 2750 & 17.5 & PB5 & 382 \\
\hline 1260 & 2740 & 78 & PB6 & 78 \\
\hline 1260 & 3560 & 20 & PB7 & 20 \\
\hline
\end{tabular}

* Life predicted from weld data is 1.7 hours and 66 hours from parent material data. 


\begin{tabular}{||c|c|c|c||}
\hline \multicolumn{4}{|c|}{ Table 4 - TEST MATRIX OF PRESSURE BURST RESULTS } \\
\hline $\begin{array}{c}\text { Temperature } \\
{ }^{\circ} \mathrm{C}\end{array}$ & $\begin{array}{c}\text { Pressure } \\
\text { psia }\end{array}$ & $\begin{array}{c}\text { Life } \\
\text { hours }\end{array}$ & $\begin{array}{c}\text { Capsule } \\
\text { Number }\end{array}$ \\
\hline 1000 & 6409 & 131.7 & PB8 \\
\hline 1000 & 6952 & 152.1 & PB9 \\
\hline 1171 & 3910 & 27.5 & PB4 \\
\hline 1171 & $2912^{\star}$ & 239.1 & PB5 \\
\hline 1260 & 2589 & 40.2 & PB6 \\
\hline 1260 & $3541^{\star \star}$ & 8.6 & PB7 \\
\hline
\end{tabular}

* Average pressure of two tests.

* Pressure prorated for test time.

\section{Test of Capsule PB5}

The first test of a girth weld capsule was made on PB5, a capsule with a tantalum fill tube. The test was conducted at $1171^{\circ} \mathrm{C}$ and reached a maximum pressure of 2907 psig. The capsule was at temperature for 104.5 hours. During this time the capsule pressure dropped to 2820 psig. The test was stopped when a large increase in helium partial pressure caused the ion pump to shut off.

When the capsule was removed from the furnace, it appeared that the fill tube had failed and not the capsule. The tantalum tube had swelled (Figure 5) just above the capsule. The tube was cut off and a new tube was EB welded in place. This new tube was an alloy of tantalum with $10 \%$ tungsten.

After capsule PB4 was tested, PB5. was installed in the furnace and retested. The test was stopped after less than 10

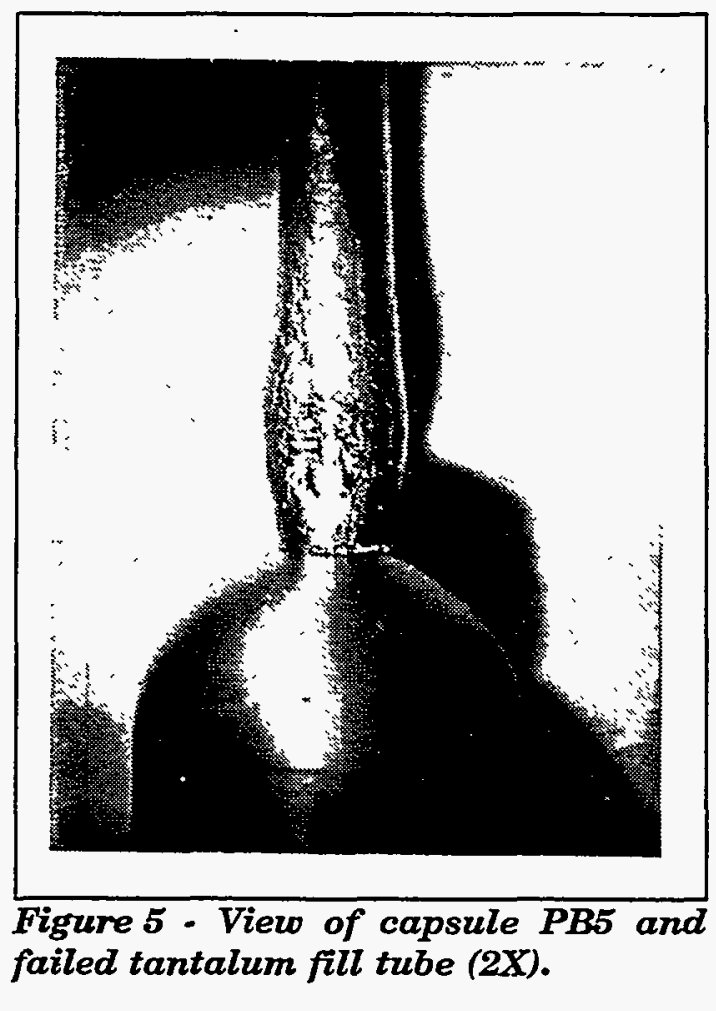




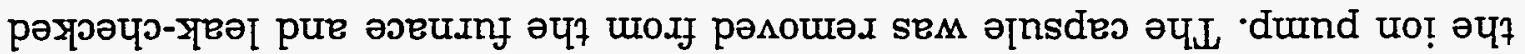

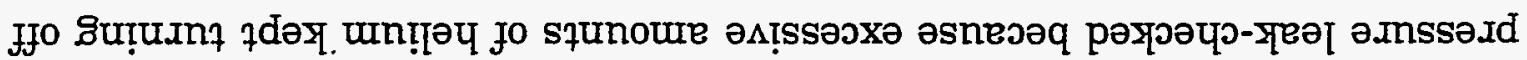

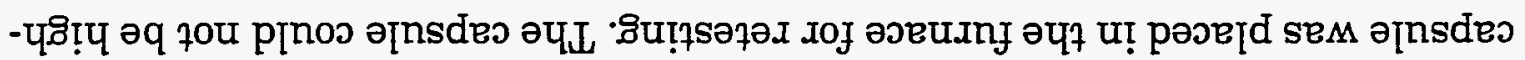

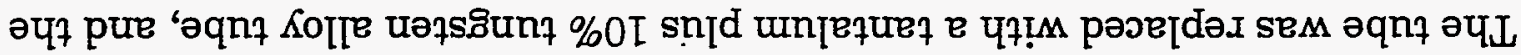

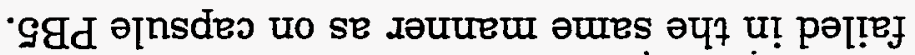

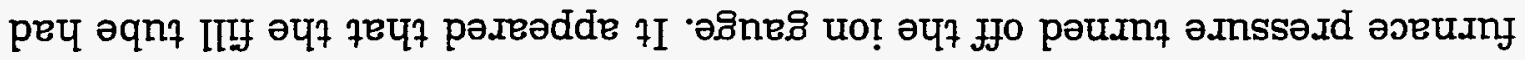

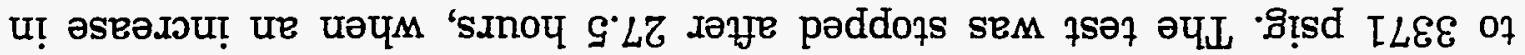

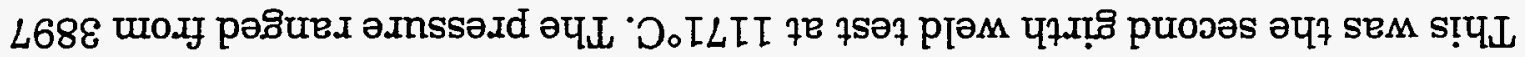

Ђgd ә[nsdeอ jo 75อ山

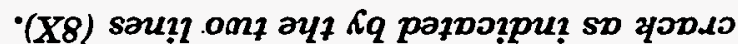

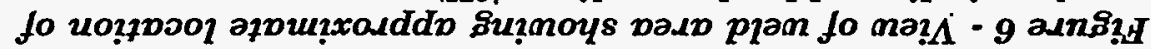

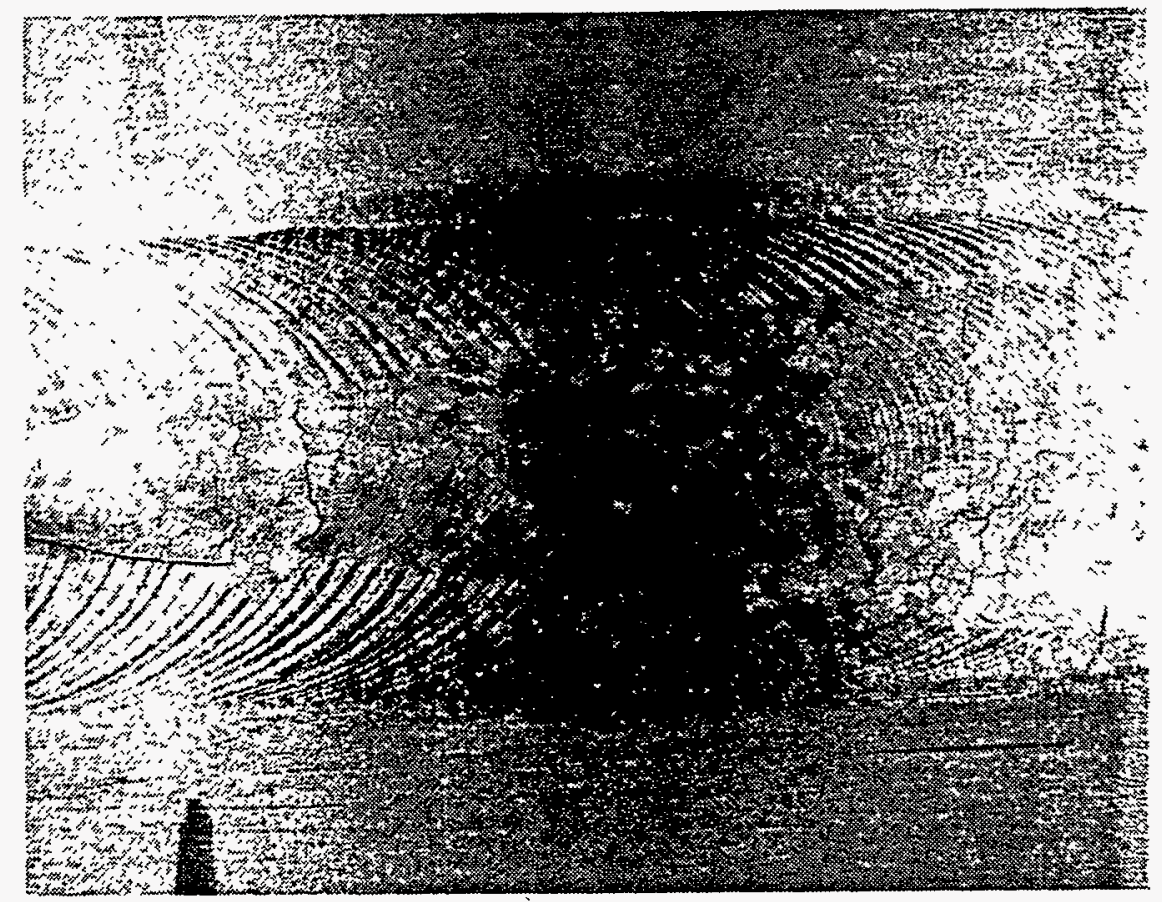

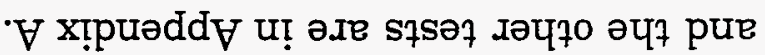

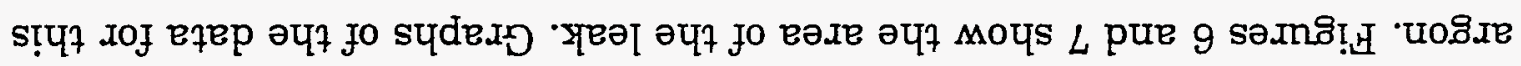

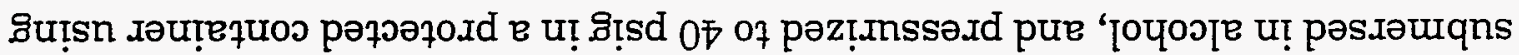

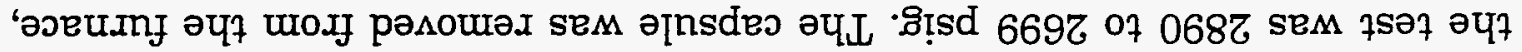

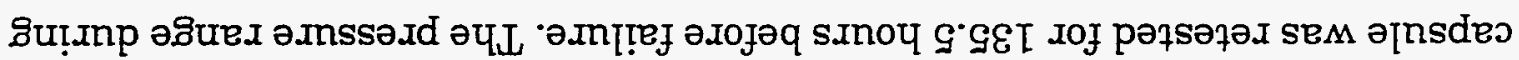

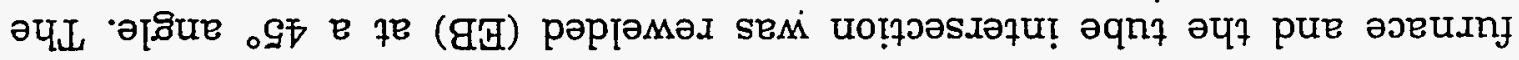

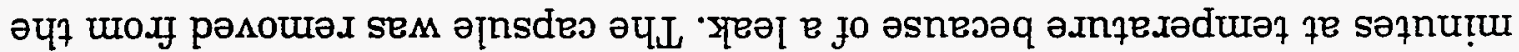


using the same method used for PB5. The leak was in the center of weld, in the same general location as the leak in PB5.

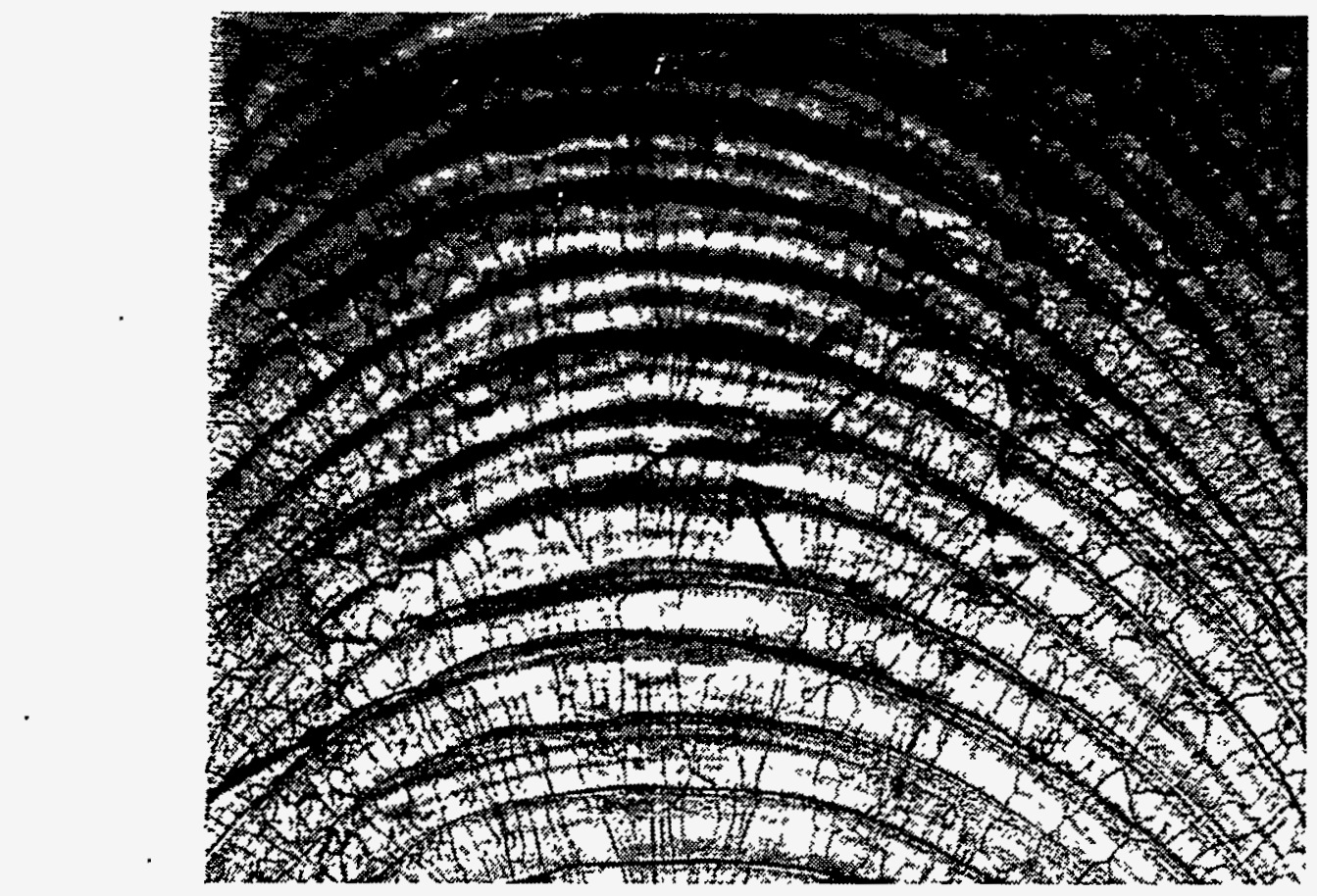

Figure 7 - Same area as in Figure 6, showing the crack (25X).

\section{Test of Capsules PB6, PB7, PB8, and PB9}

The next four capsules to be tested were the same size and used the tantalum plus $10 \%$ tungsten alloy fill tube. The failure mode was the same as in the previous two tests (PB4 and PB5). The location of the leak was in the center of the weld. Table 5 gives the approximate location of the defect in relation to the end of the weld. Figures 8 and 9 show the capsule, fill tube, and the end of the weld of capsule PB7. By definition the crack is counter clockwise (CCW) from the end of the weld.

\begin{tabular}{|c|c|c||}
\hline \multicolumn{3}{||c|}{$\begin{array}{c}\text { Table 5 - DEFECT LOCATION } \\
\text { FROM END OF WELD }\end{array}$} \\
\hline $\begin{array}{c}\text { Capsule } \\
\text { Number }\end{array}$ & Direction & $\begin{array}{c}\text { Location } \\
\text { Degrees }\end{array}$ \\
\hline PB4 & CCW & $20-30$ \\
\hline PB5 & CCW & $20-30$ \\
\hline PB6 & CCW & $20-30$ \\
\hline PB7 & CCW & $0-5$ \\
\hline PB8 & CCW & $20-30$ \\
\hline PB9 & CW & $90-100$ \\
\hline
\end{tabular}




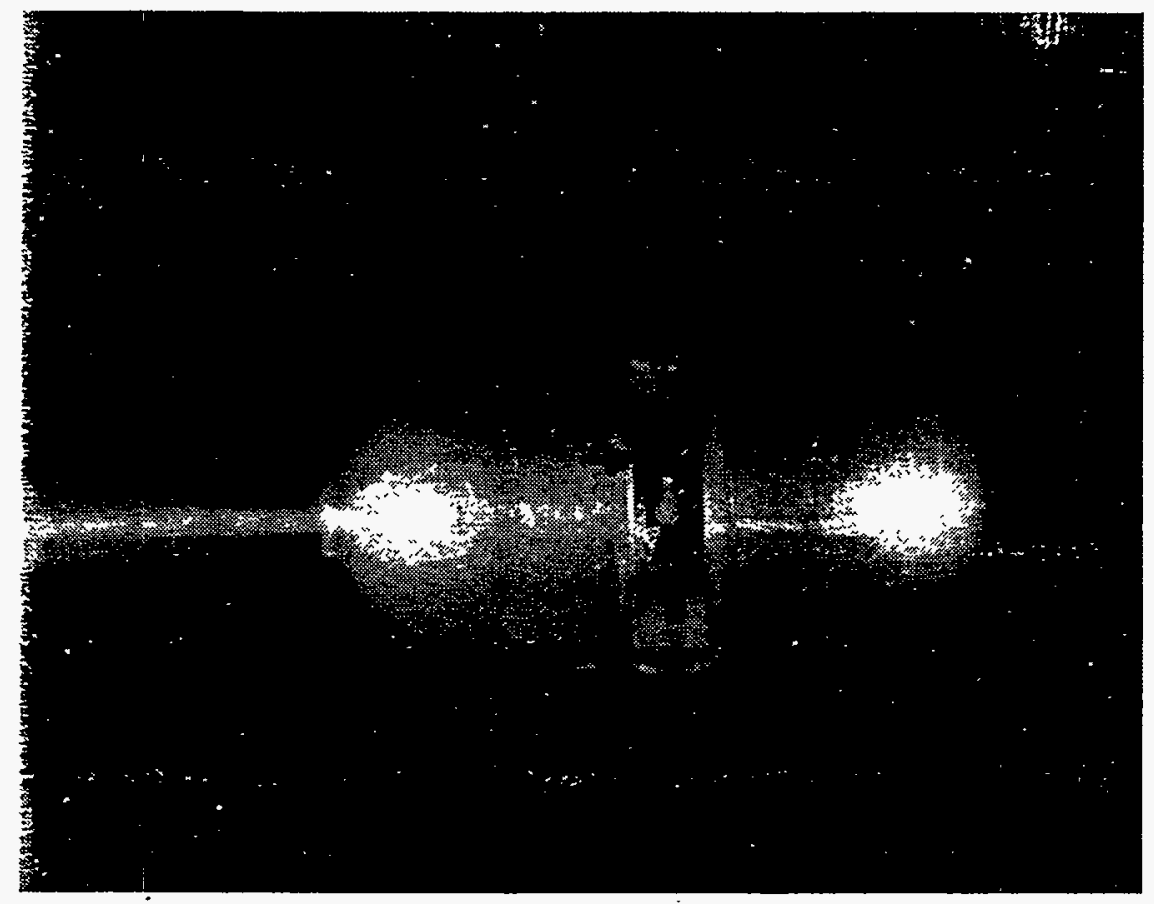

Figure 8 - View of capsule showing relation from end of weld to approximate location of crack (1X).

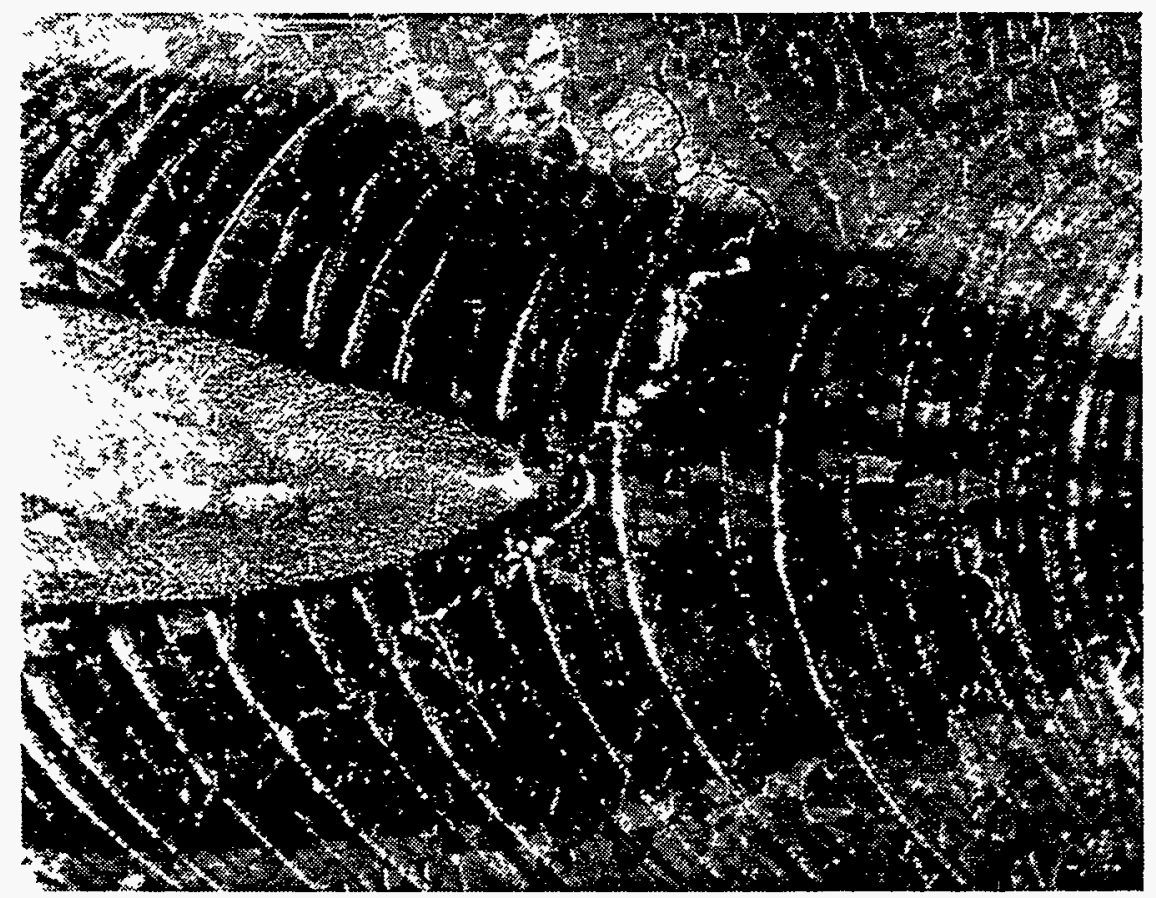

Figure 9 -.View of capsule PB7 showing crack at end of weld overlap (15X). 


\section{Evaluation Of ORNL Regression Model}

To evaluate the ORNL regression model, the percent error from calculated life to actual life was determined for each test. The average error was $57.6 \%$ with a standard deviation of 91.6. This equation does not predict failure life satisfactorily. Table 6 gives a summary of this evaluation.

\begin{tabular}{|c|c|c|c|c|c||}
\hline \multicolumn{6}{|c|}{ Table 6 - ORNL PREDICTED LIFE COMPARED TO ACTUAL TEST LIFE } \\
\hline $\begin{array}{c}\text { Test } \\
\begin{array}{c}\text { Temperature } \\
{ }^{\circ} \mathrm{C}\end{array}\end{array}$ & $\begin{array}{c}\text { Test } \\
\text { Pressure } \\
\text { psig }\end{array}$ & $\begin{array}{c}\text { Stress } \\
\text { psi }\end{array}$ & $\begin{array}{c}\text { Predicted } \\
\text { ORNL_Time } \\
\text { hours }\end{array}$ & $\begin{array}{c}\text { Actual Test } \\
\text { Time } \\
\text { hours }\end{array}$ & $\begin{array}{c}\text { Change } \\
\text { percent }\end{array}$ \\
\hline 1000 & 6490 & 46786 & 97.5 & 131.7 & -26.0 \\
\hline 1000 & 6952 & 50750 & 63.5 & 152.1 & -58.2 \\
\hline 1171 & 3910 & 28543 & 59.7 & $27.5 \cdot$ & +117.1 \\
\hline 1171 & 2912 & 21258 & 282.4 & 239.1 & +18.1 \\
\hline 1260 & 2589 & 18900 & 104.8 & 40.2 & +160.7 \\
\hline 1260 & 3541 & 25849 & 20.1 & 8.6 & +133.7 \\
\hline
\end{tabular}

\section{Conclusions}

The end cap weld design was unacceptable, with failure in three minutes or less. The results of the girth weld design tests were favorable. All of the girth weld capsules failed in the center of the weld and five of the six in the same area from the end of the weld.

The ORNL regression model does not predict failure life for welded T-111.

\section{Acknowledgments}

The author would like to thank John L. Fisher, Francis A Koehler, Richard McNeese, Patrick M. Schleitweiler, Lynn A. Sowders, and G. Scott West for contributing to the work described in this report. 


\section{Appendix A \\ Graphs}

A. Capsule PB4

page

1. Pressure as a function of Time, Start to $1171^{\circ} \mathrm{C} \ldots \ldots .14$

2. Pressure as a function of Time, $1171^{\circ} \mathrm{C}$ to Failure .... 14

3. Helium as a function of Time, Start to $1171^{\circ} \mathrm{C} \ldots \ldots \ldots 15$

B. Capsule PB5

4. Helium as a function of Time, $1171^{\circ} \mathrm{C}$ to Failure ..... 15

1. Pressure as a function of Time, Start to $1171^{\circ} \mathrm{C} \ldots \ldots .16$

2. Pressure as a function of Time, $1171^{\circ} \mathrm{C}$ to Tube Failure . 16

3. Helium as a function of Time, Start to $1171^{\circ} \mathrm{C} \ldots \ldots \ldots 17$

4. Helium as a function of Time, $1171^{\circ} \mathrm{C}$ to Tube Failure . . 17

C. Second Retest of Capsule PB5

1. Pressure as a function of Time, Start to $1171^{\circ} \mathrm{C} \ldots \ldots 18$

2. Pressure as a function of Time, $1171^{\circ} \mathrm{C}$ to Failure .... 18

3. Helium as a function of Time, Start to $1171^{\circ} \mathrm{C} 19 \ldots \ldots .19$

4. Helium as a function of Time, Start to Failure . . . . . . 19

D. Capsule PB6

1. Pressure as a function of Time, Start to $1260^{\circ} \mathrm{C} \ldots \ldots 20$

2. Pressure as a function of Time, $1260^{\circ} \mathrm{C}$ to Failure .... 20

3. Helium as a function of Time, Start to $1260^{\circ} \mathrm{C} \ldots \ldots \ldots 21$

4. Helium as a function of Time, $1260^{\circ} \mathrm{C}$ to Failure . . . . 21 E. Capsule PB7

1. Pressure as a function of Time, Start to $1260^{\circ} \mathrm{C} \ldots \ldots 22$

2. Pressure as a function of Time, $1260^{\circ} \mathrm{C}$ to Failure .... 22

3. Helium as a function of Time, Start to $1260^{\circ} \mathrm{C} \ldots \ldots \ldots 23$

4. Helium as a function of Time, Start to Failure . . . . . 23 F. Retest of Capsule PB7

1. Pressure as a function of Time, Start to Failure . . . . . 24

2. Pressure as a function of Time, $1260^{\circ} \mathrm{C}$ to Failure . . . . 24

3. Helium as a function of Time, Start to $1260^{\circ} \mathrm{C} \ldots \ldots .25$ G. Capsule PB8

4. Helium as a function of Time, Start to Failure . . . . . 25

1. Pressure as a function of Time, Start to $1000^{\circ} \mathrm{C} \ldots \ldots 26$

2. Pressure as a function of Time, 40 Hours to Failure . . . 26

3. Helium as a function of Time, Start to $1000^{\circ} \mathrm{C} \ldots \ldots .27$

H. Capsule PB9

4. Helium as a function of Time, 40 Hours to Failure . . . . 27

1. Pressure as a function of Time, Start to $1000^{\circ} \mathrm{C} \ldots \ldots 28$

2. Pressure as a function of Time, $1000^{\circ} \mathrm{C}$ to Failure . . . 28

3. Helium as a function of Time, Start to $1000^{\circ} \mathrm{C} \ldots \ldots .29$

4. Helium as a function of Time, $1000^{\circ} \mathrm{C}$ to Failure . . . . 29 
PB4

START TO 1171 DEG. C

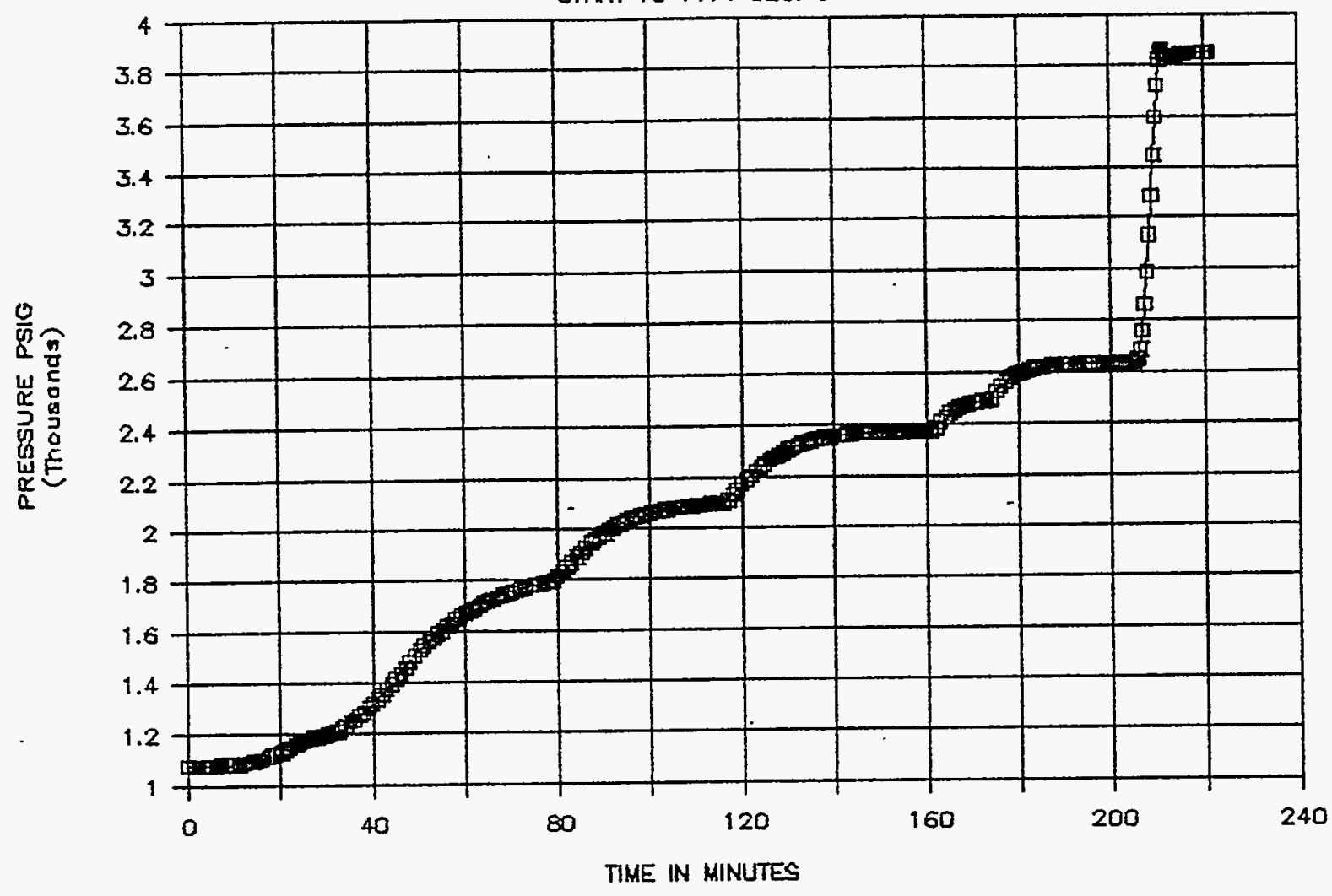

PB4

1171 DEG. C TO FALURE

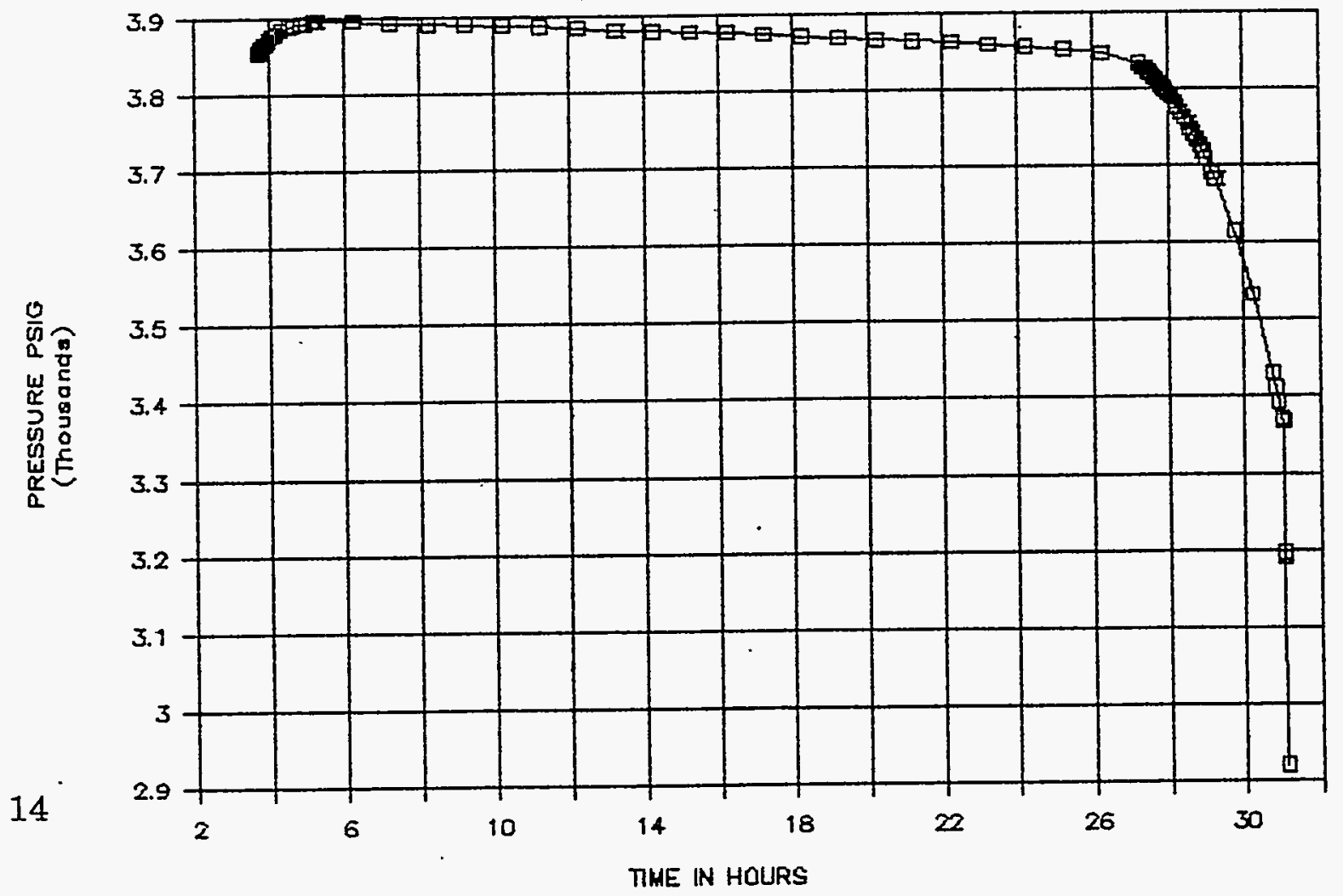




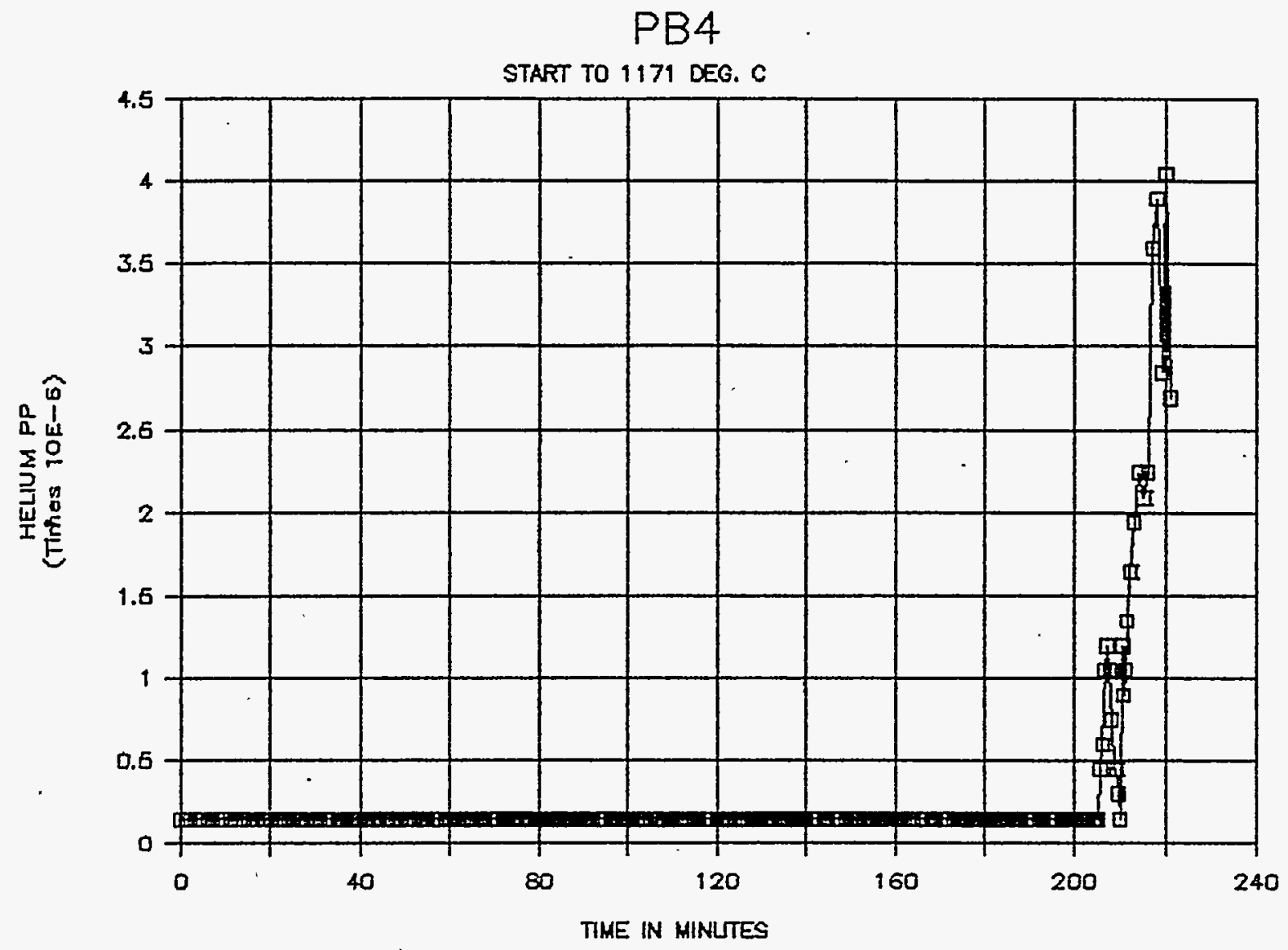

PB4

1171 DEG. C TO FALUURE

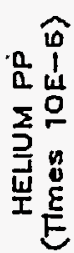

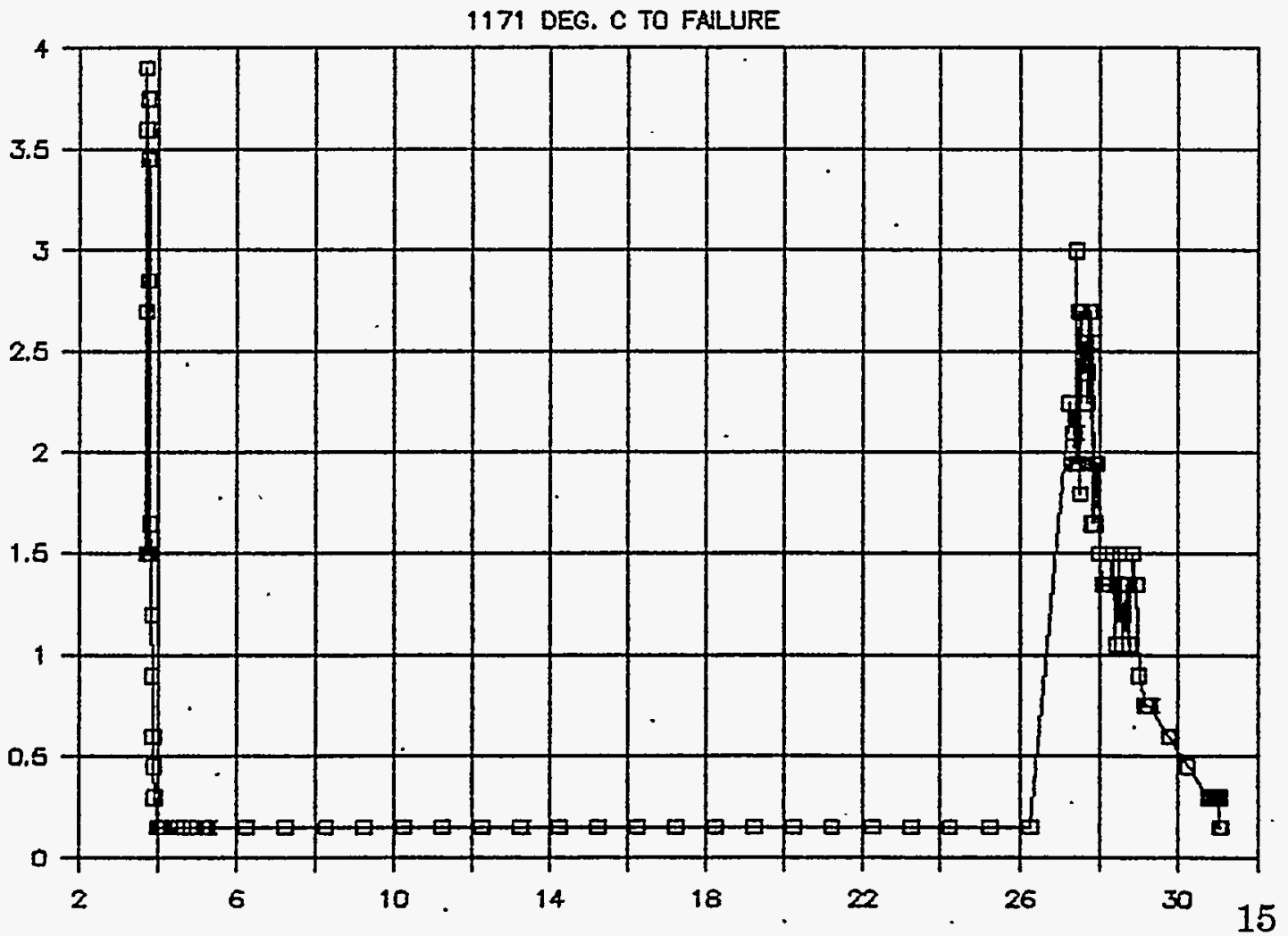

TIME IN HOURS 
PB5

START TO 1171 LEG. C

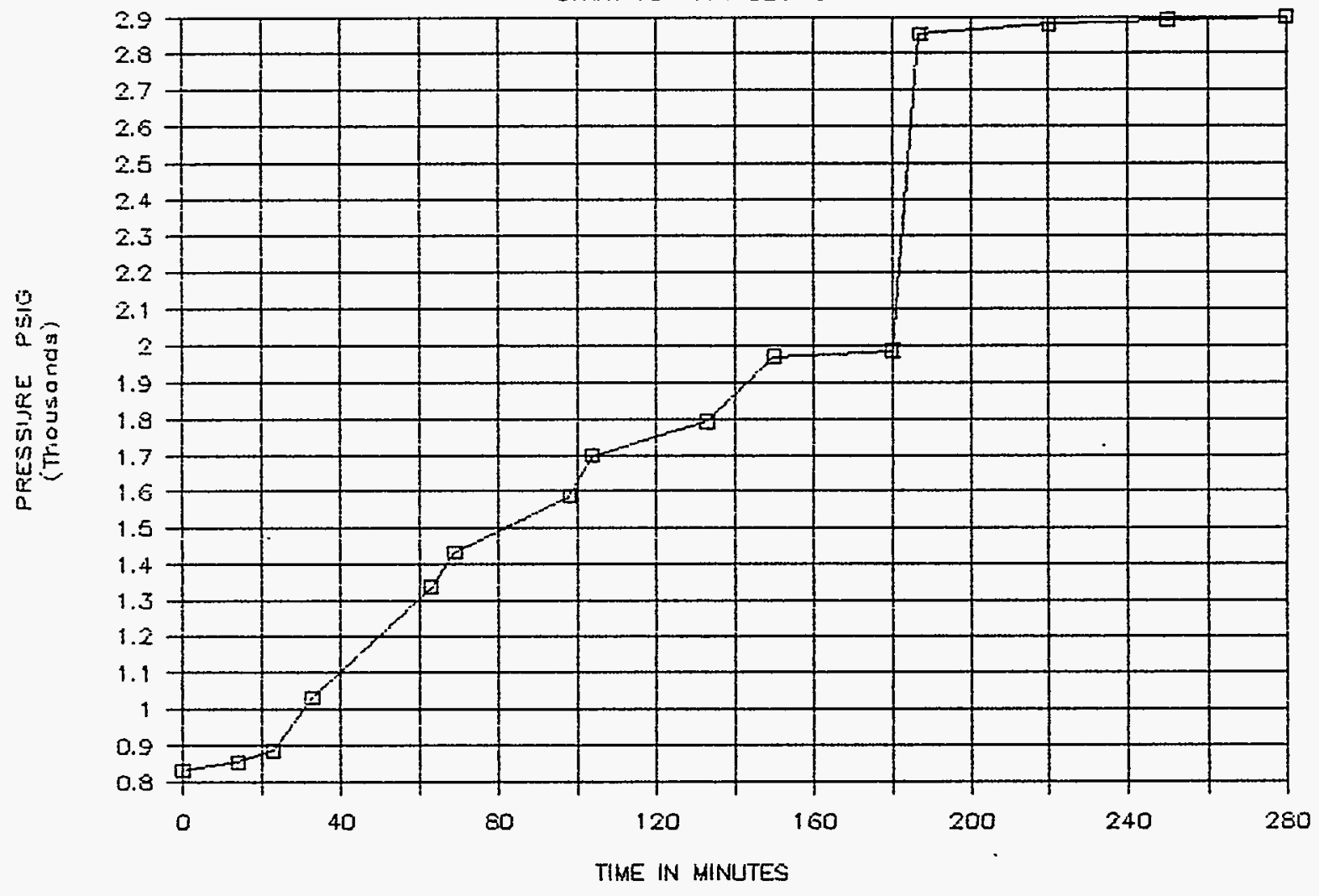

PB5

1171 DEG. C TO FAILURE (TJBE)

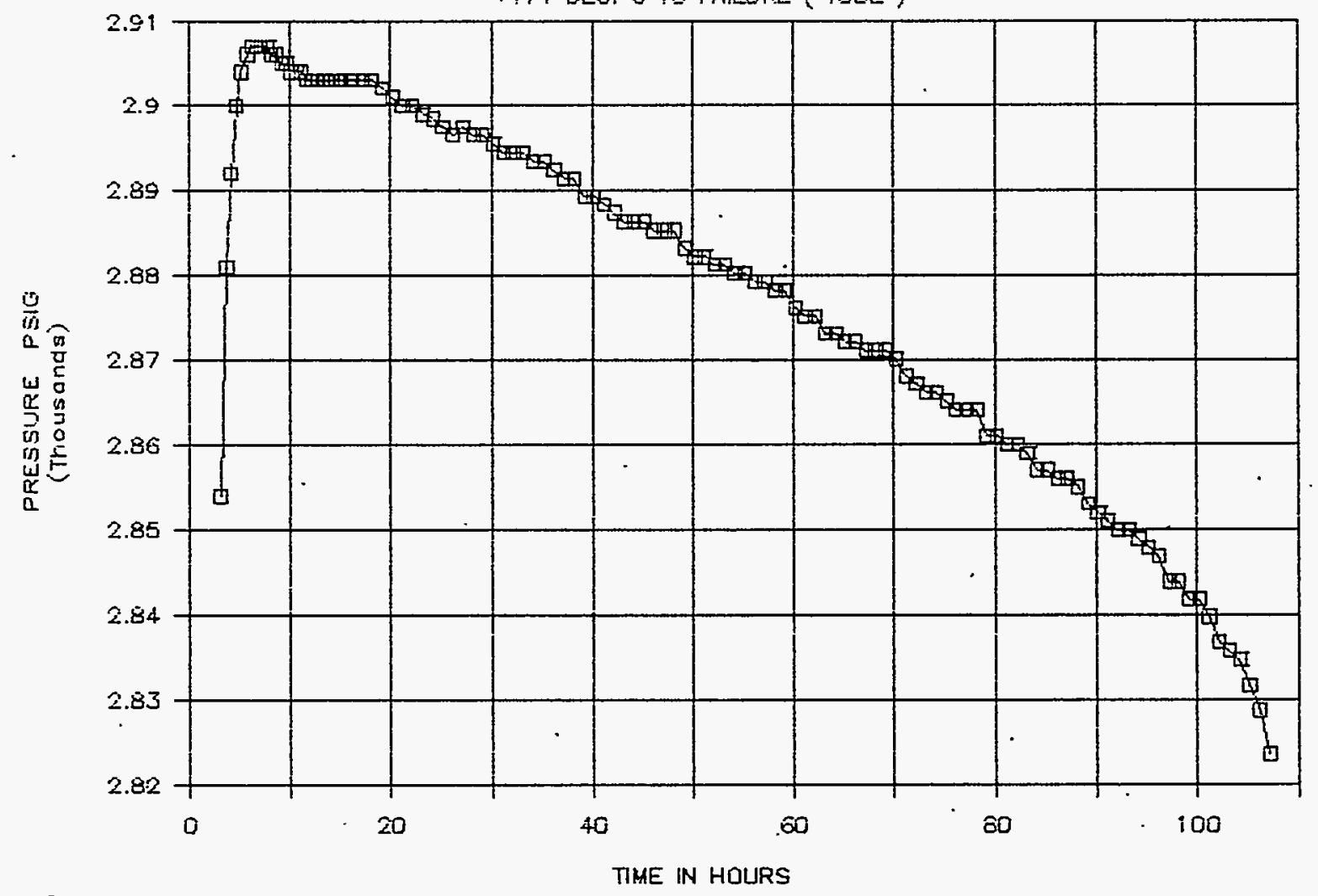



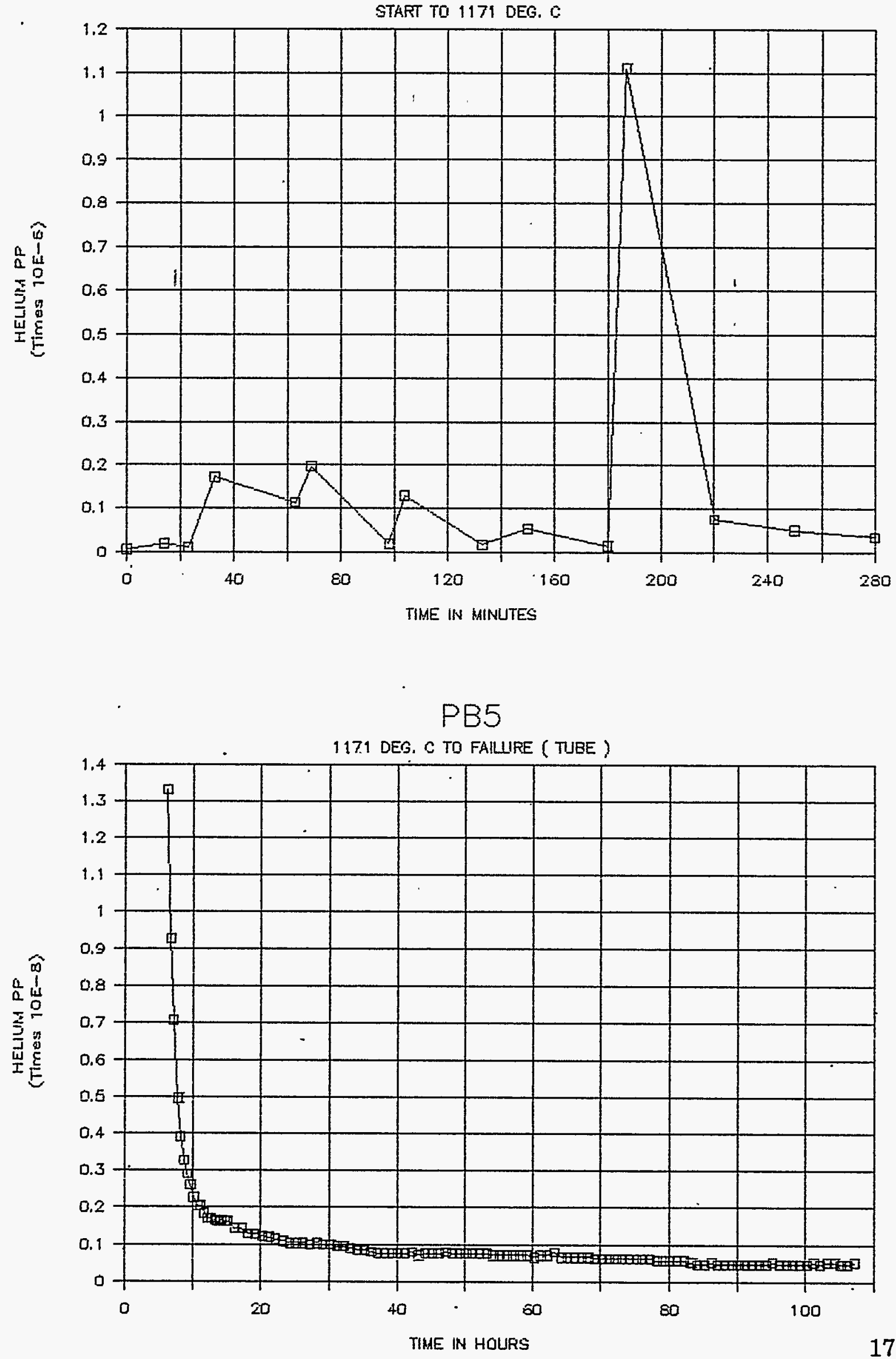
SECOND RETEST OF PB5

START TO 1171 DEG. C
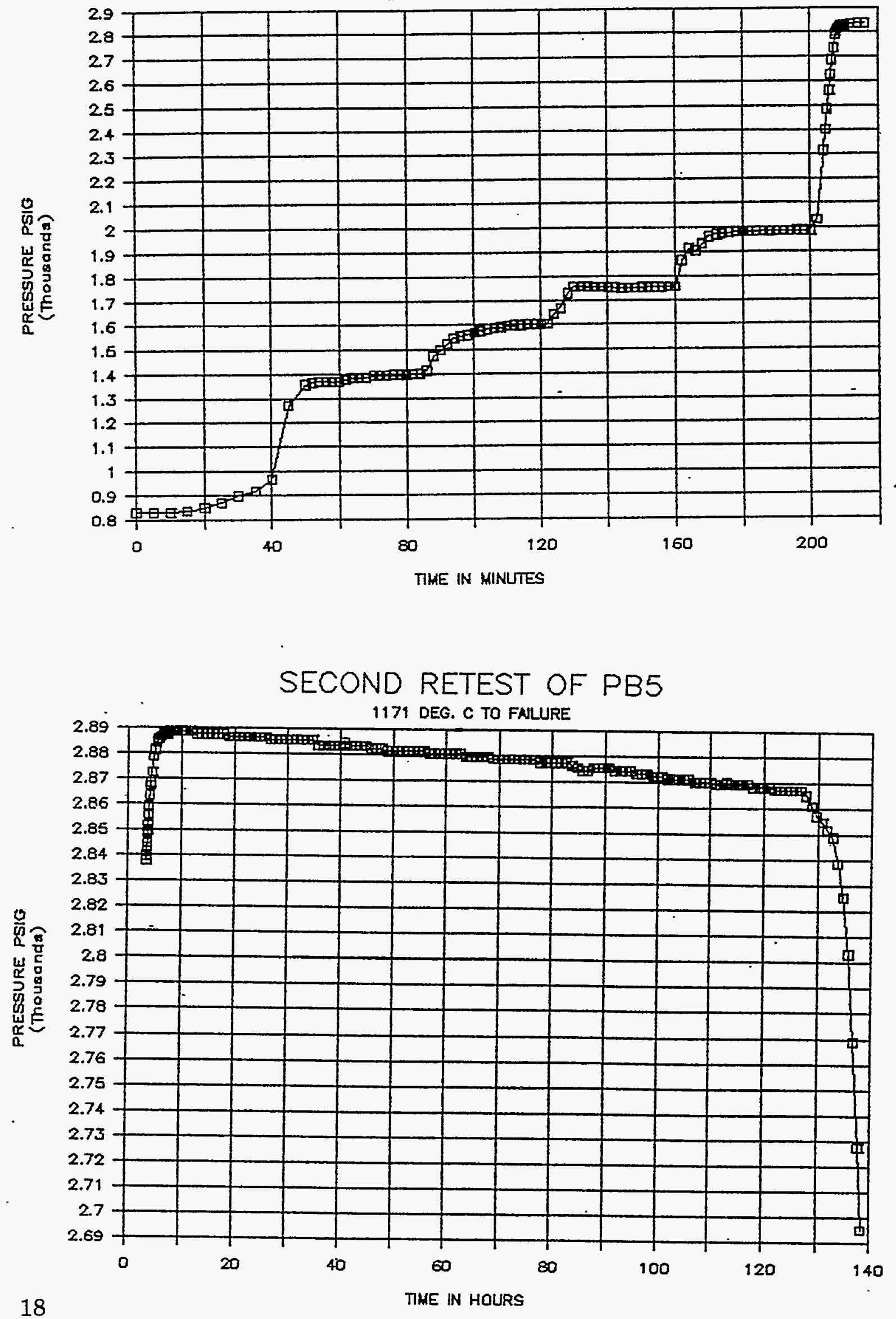


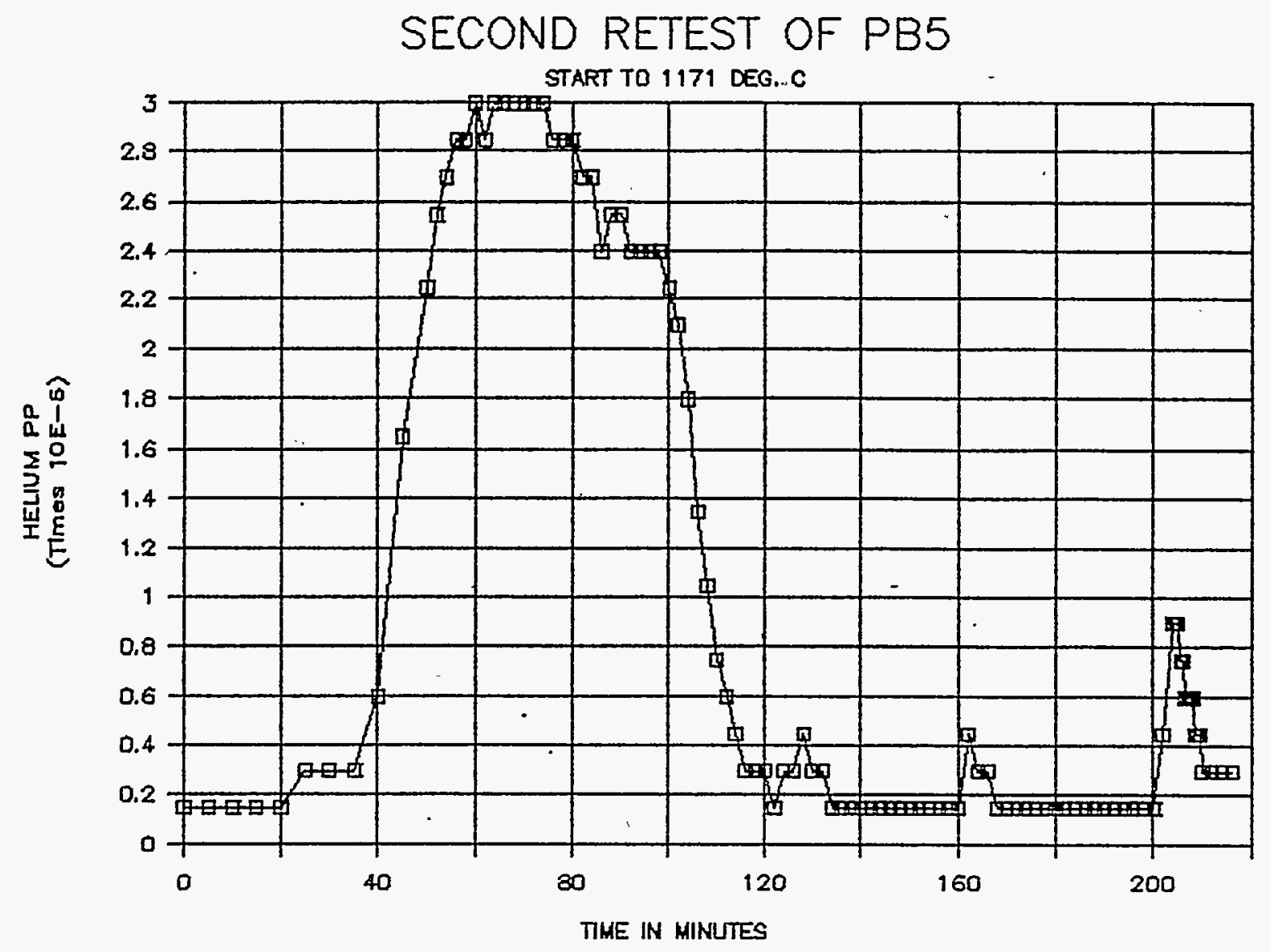

SECOND RETEST OF PB5

START TO FALUURE

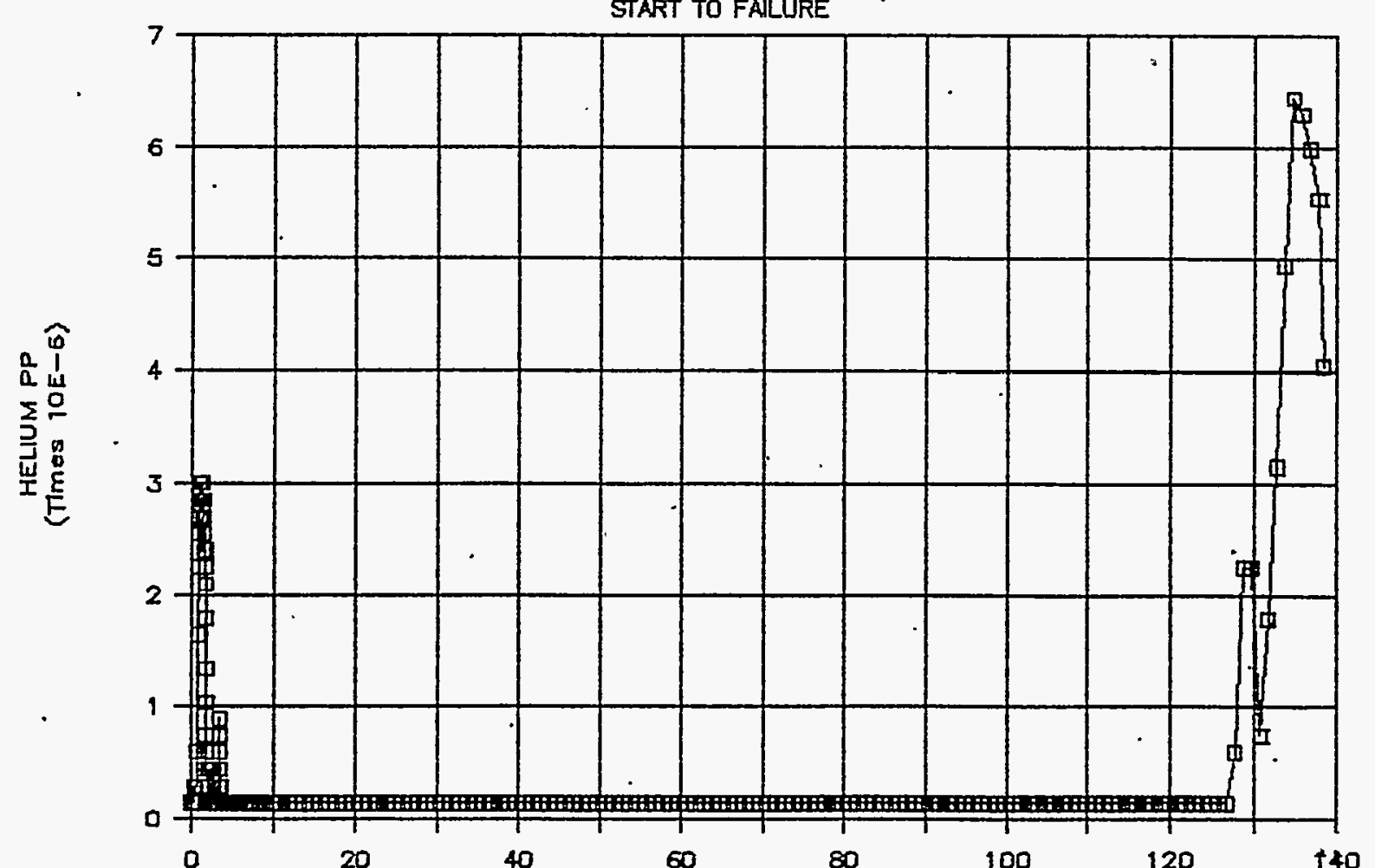

TIME IN HOURS 
START TO 1260 DEG, C

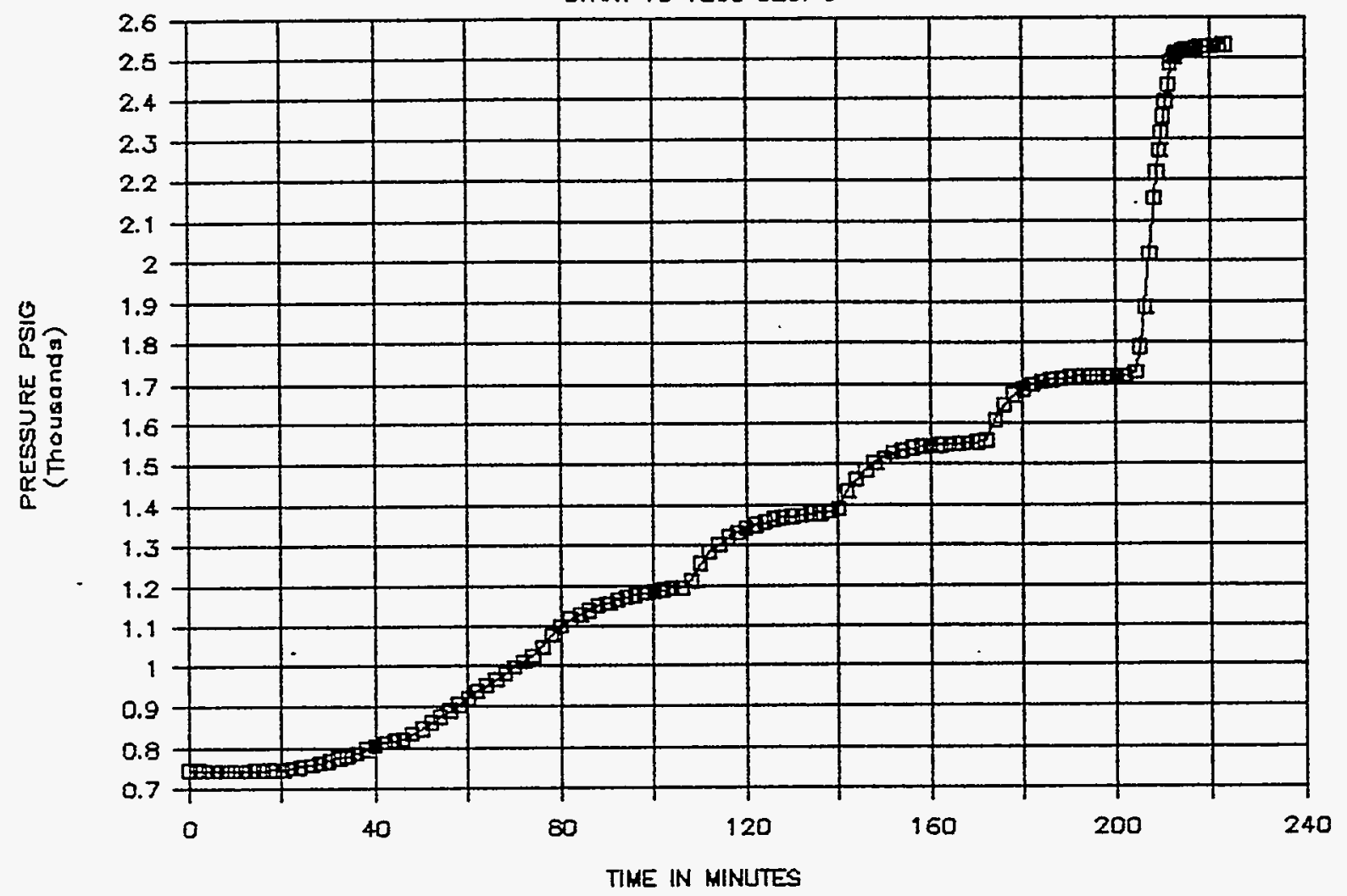

PB6

1260 DEG. C TO FAIUURE

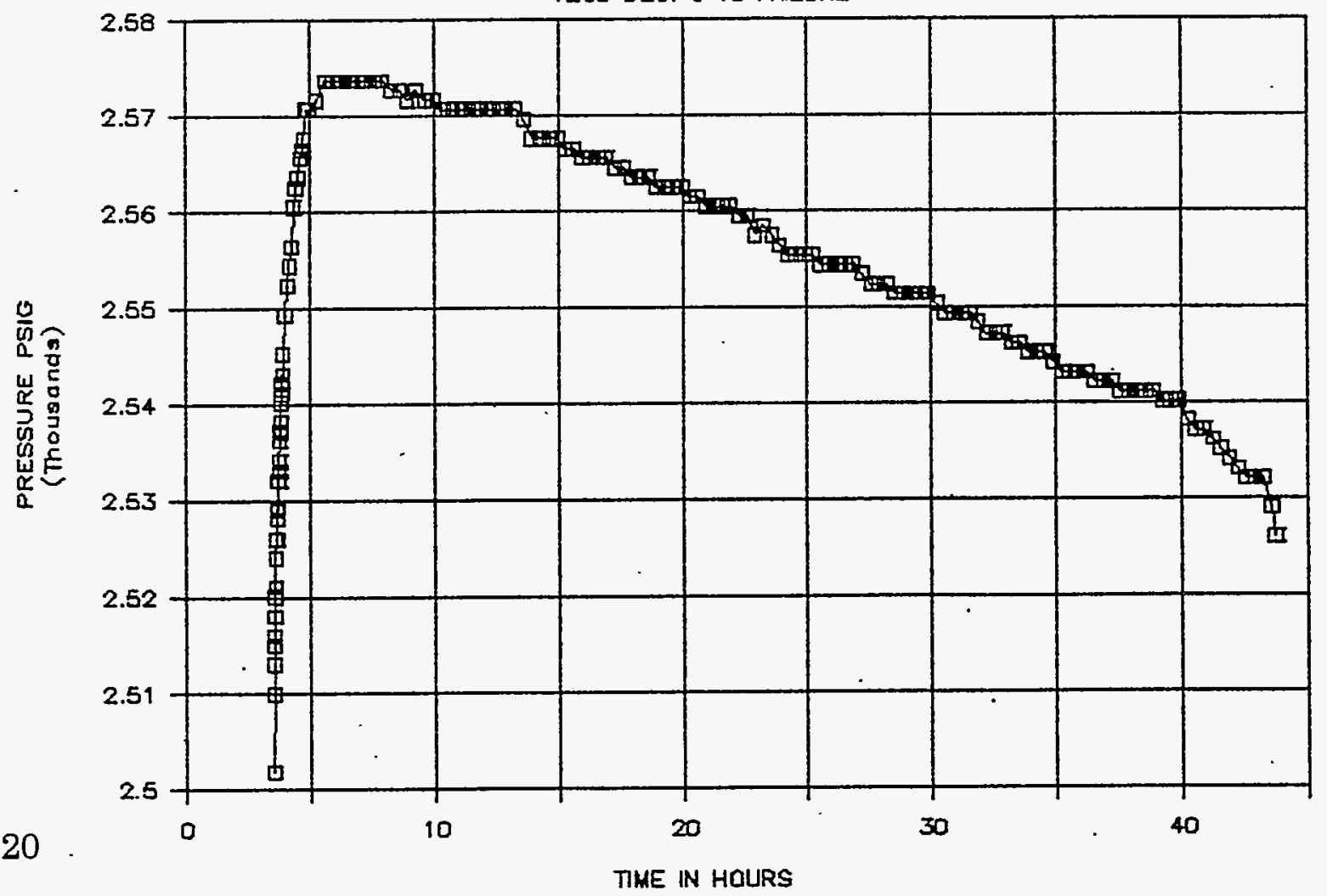



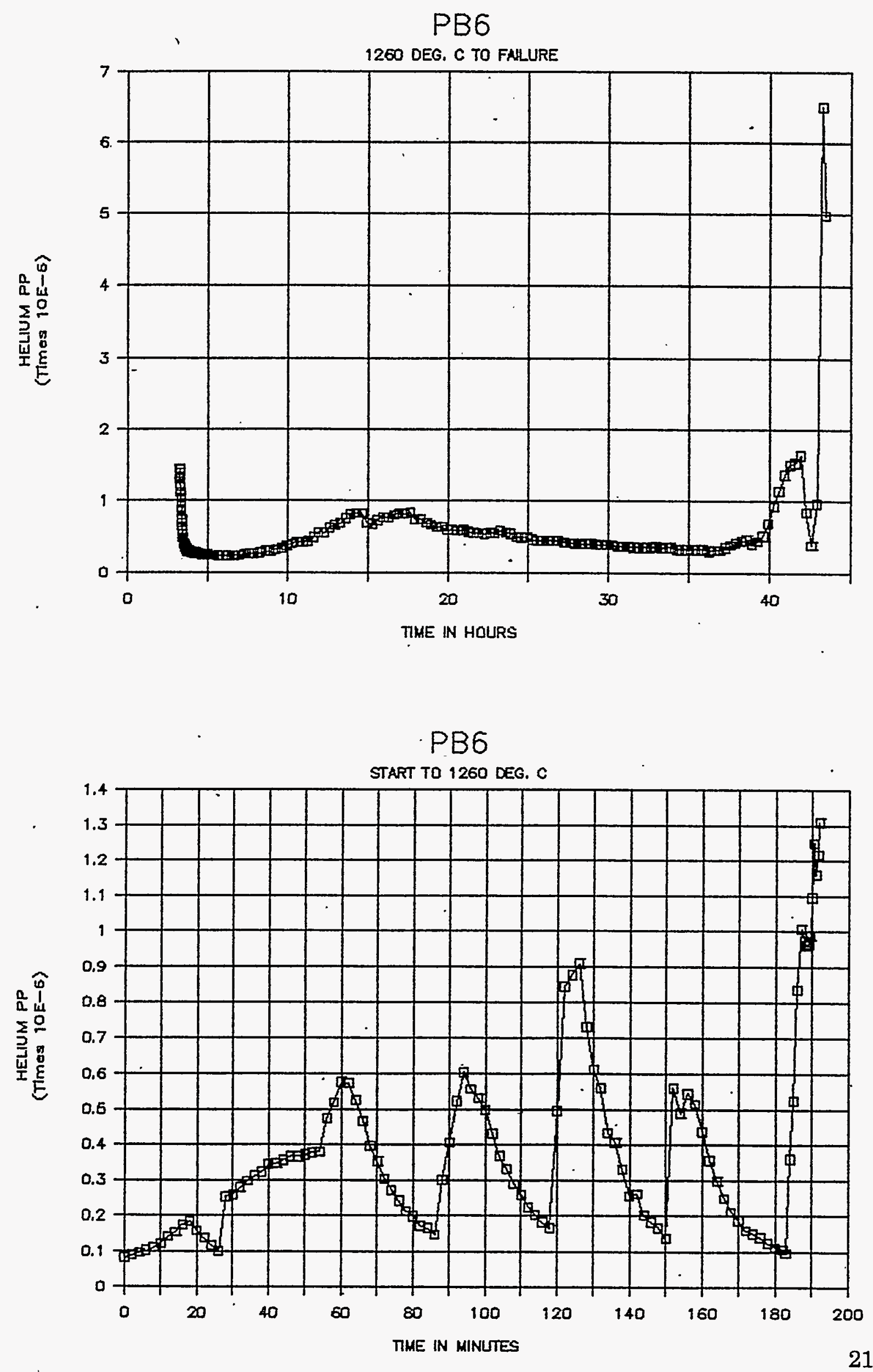
PB7

START TO 1260 DEG. C

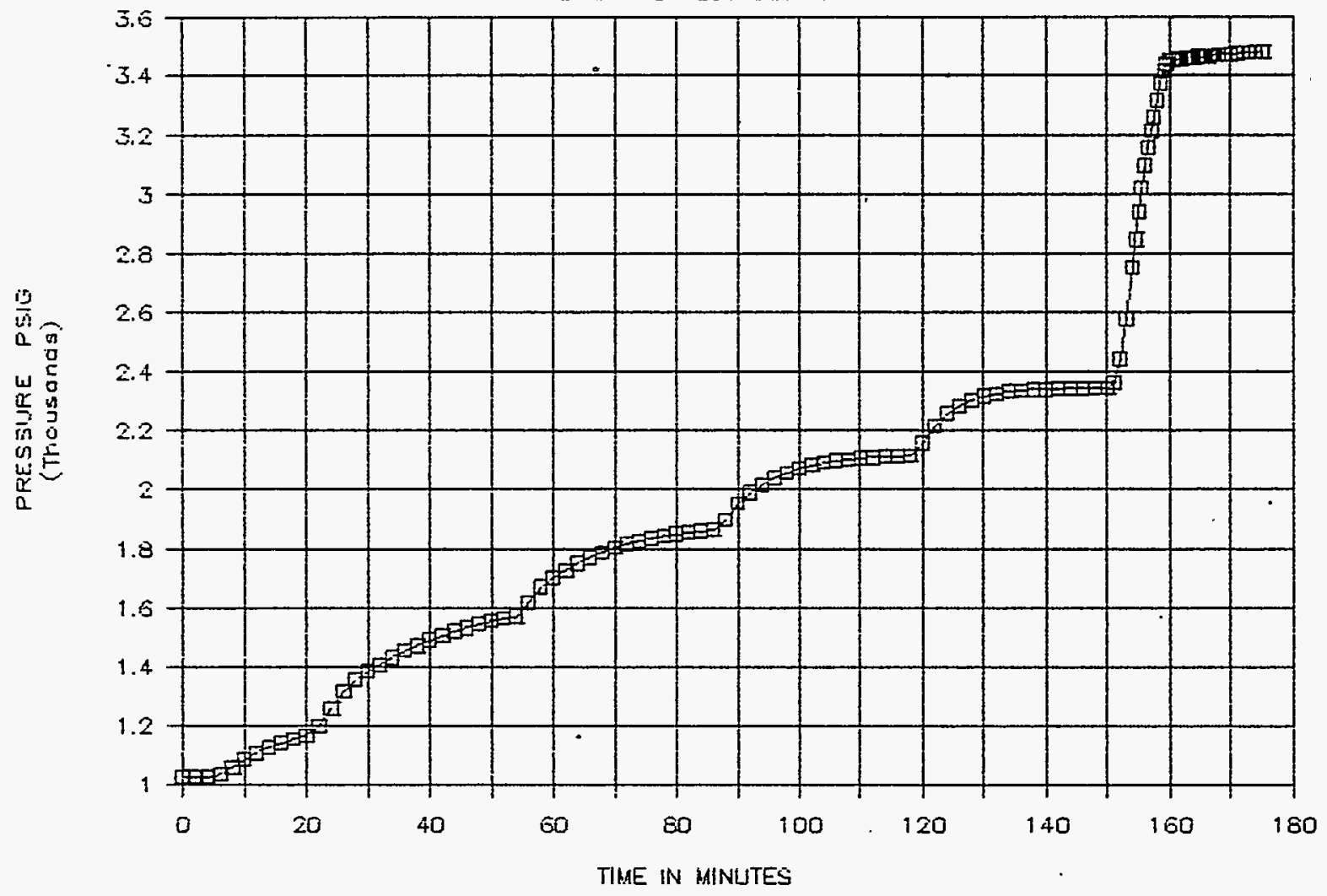

PB7

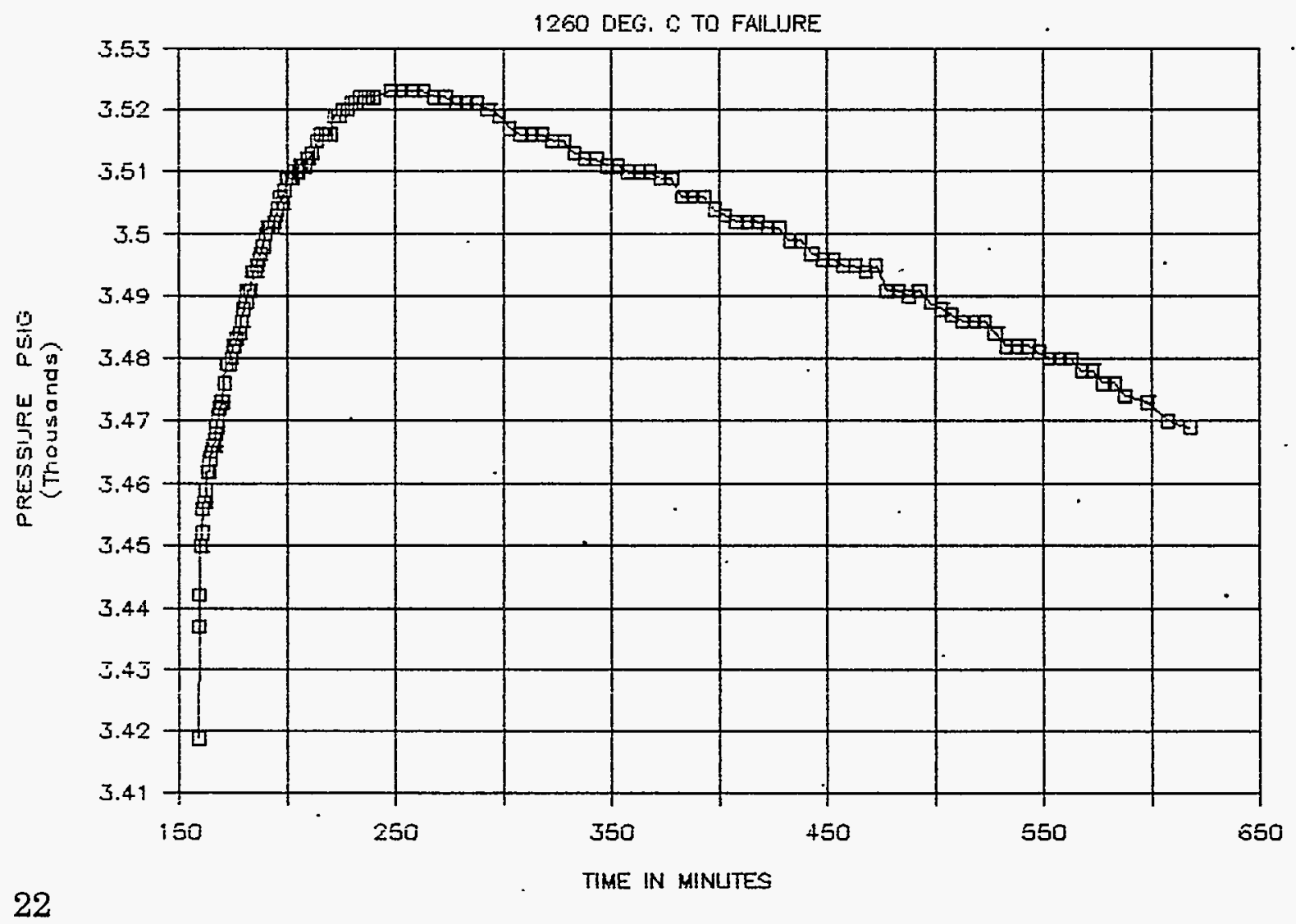




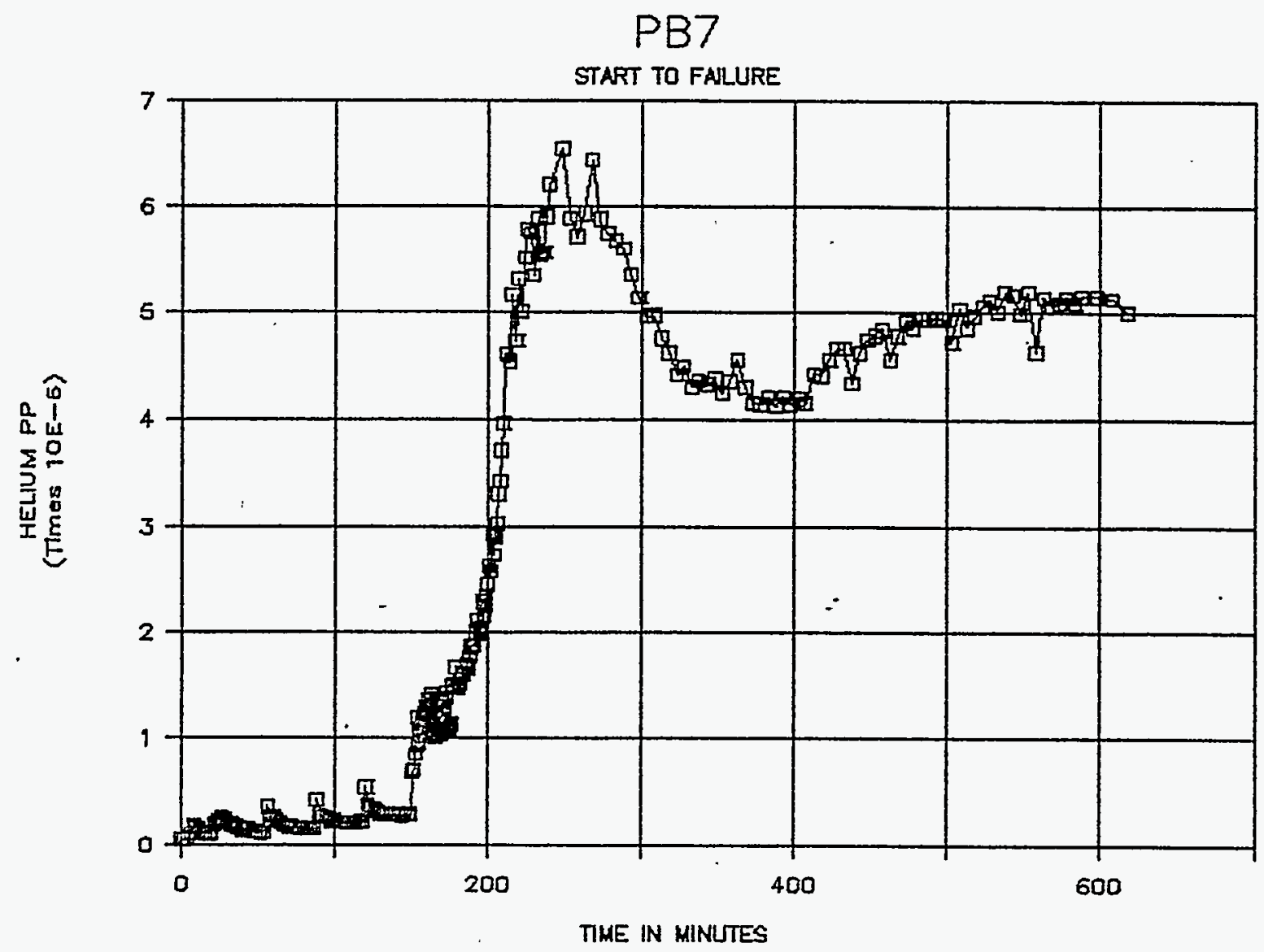

PB7

START TO 1260 DEG. C

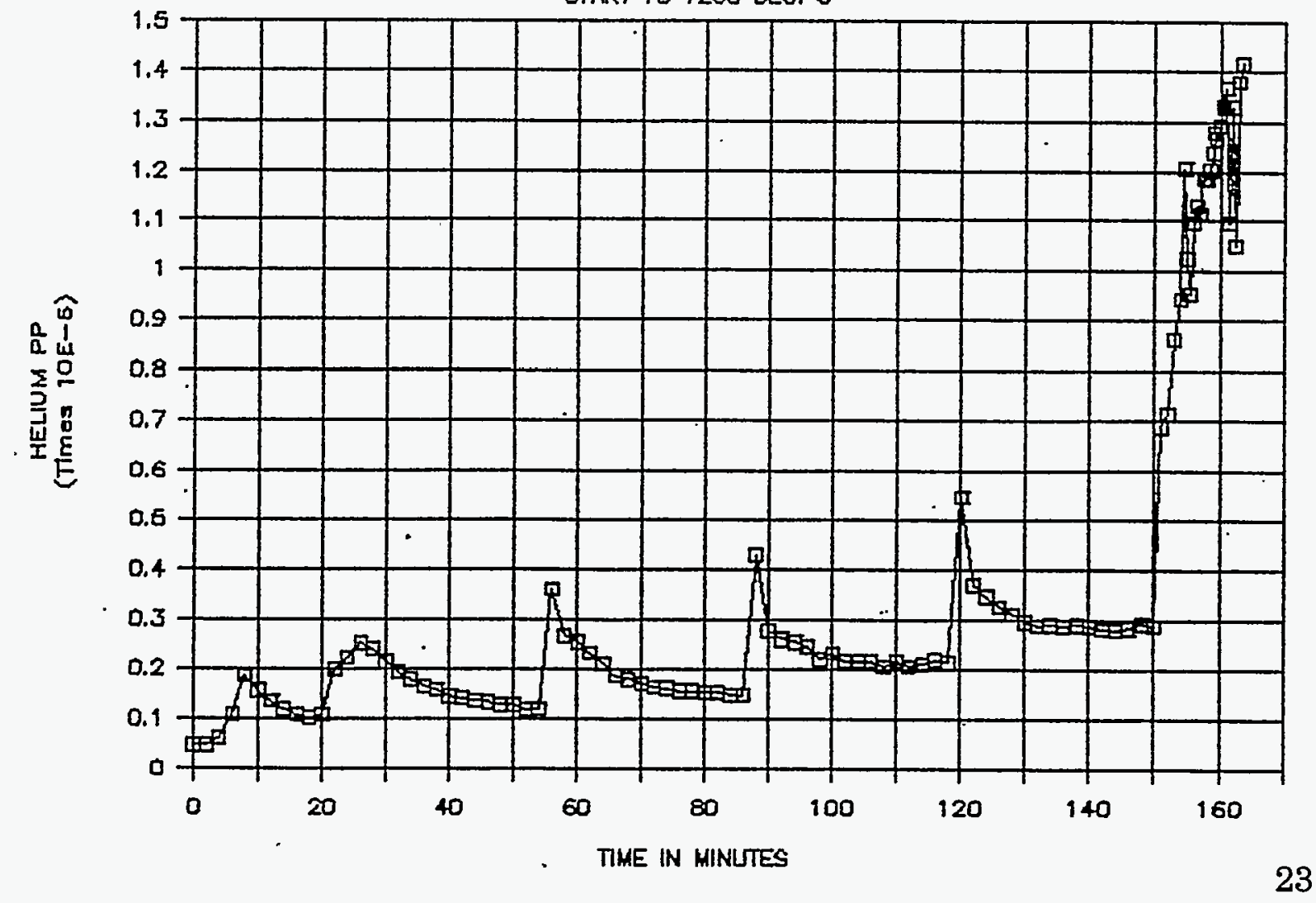



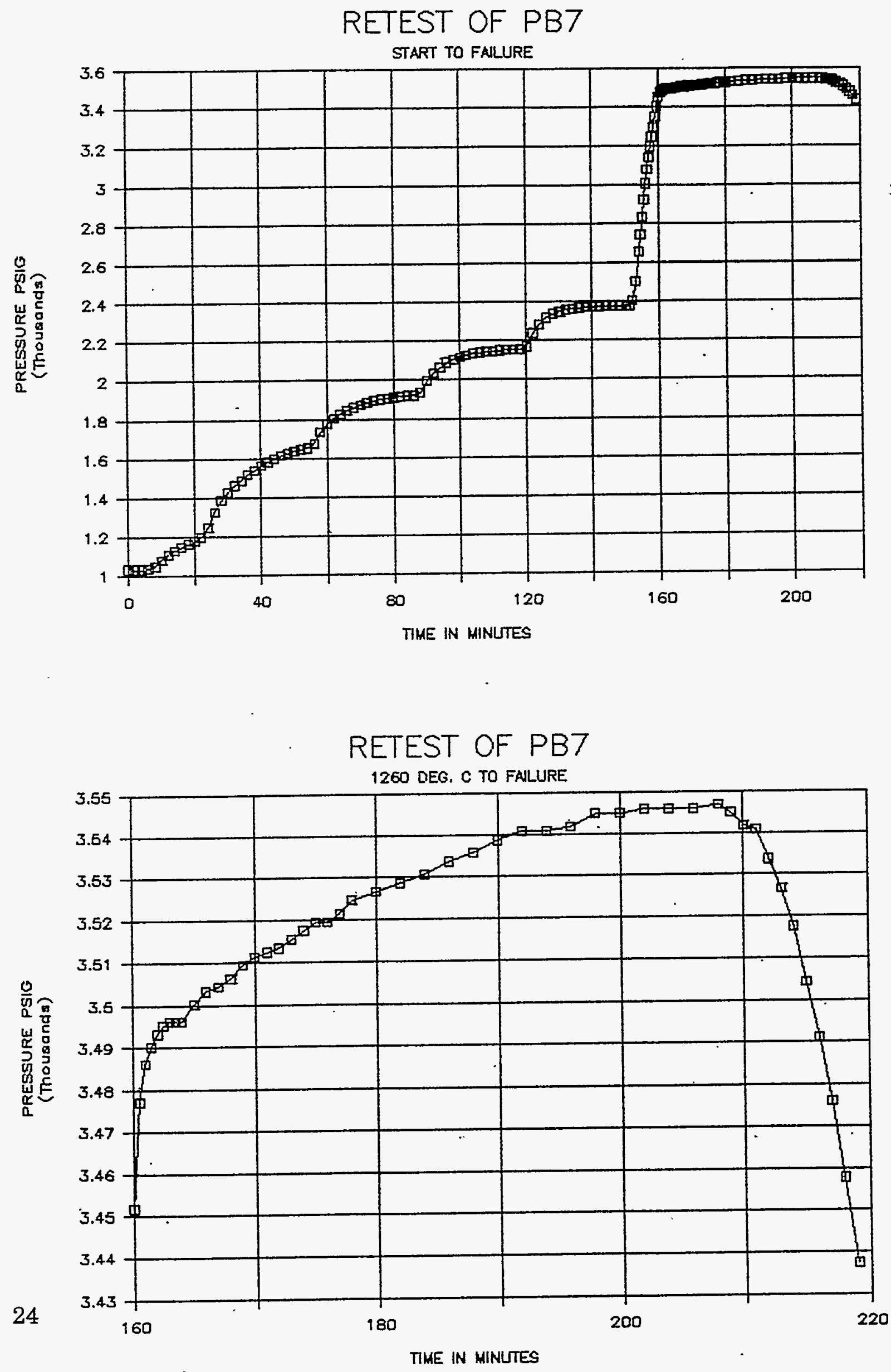

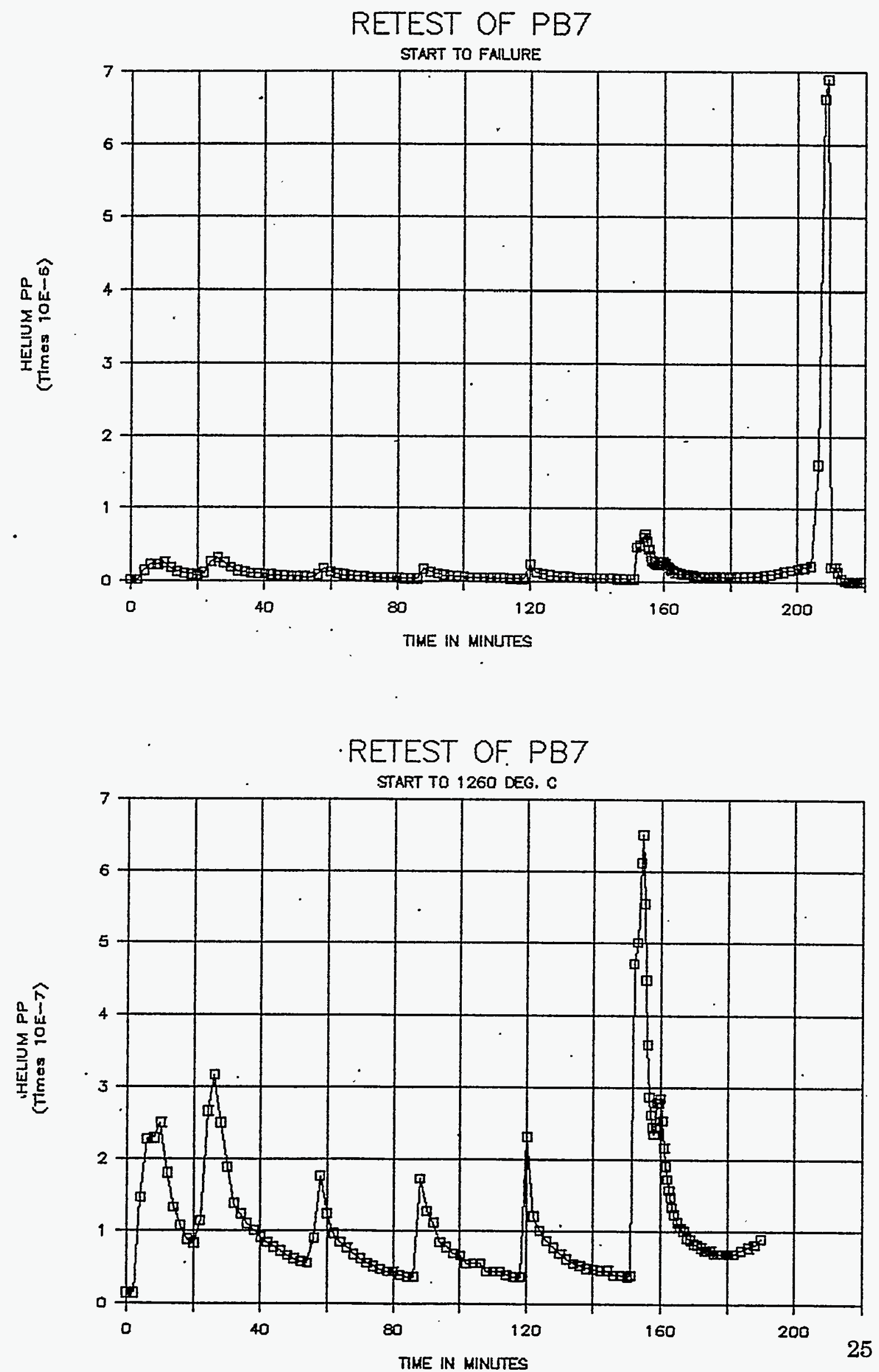
PB8

START TO 1000 LEG. C

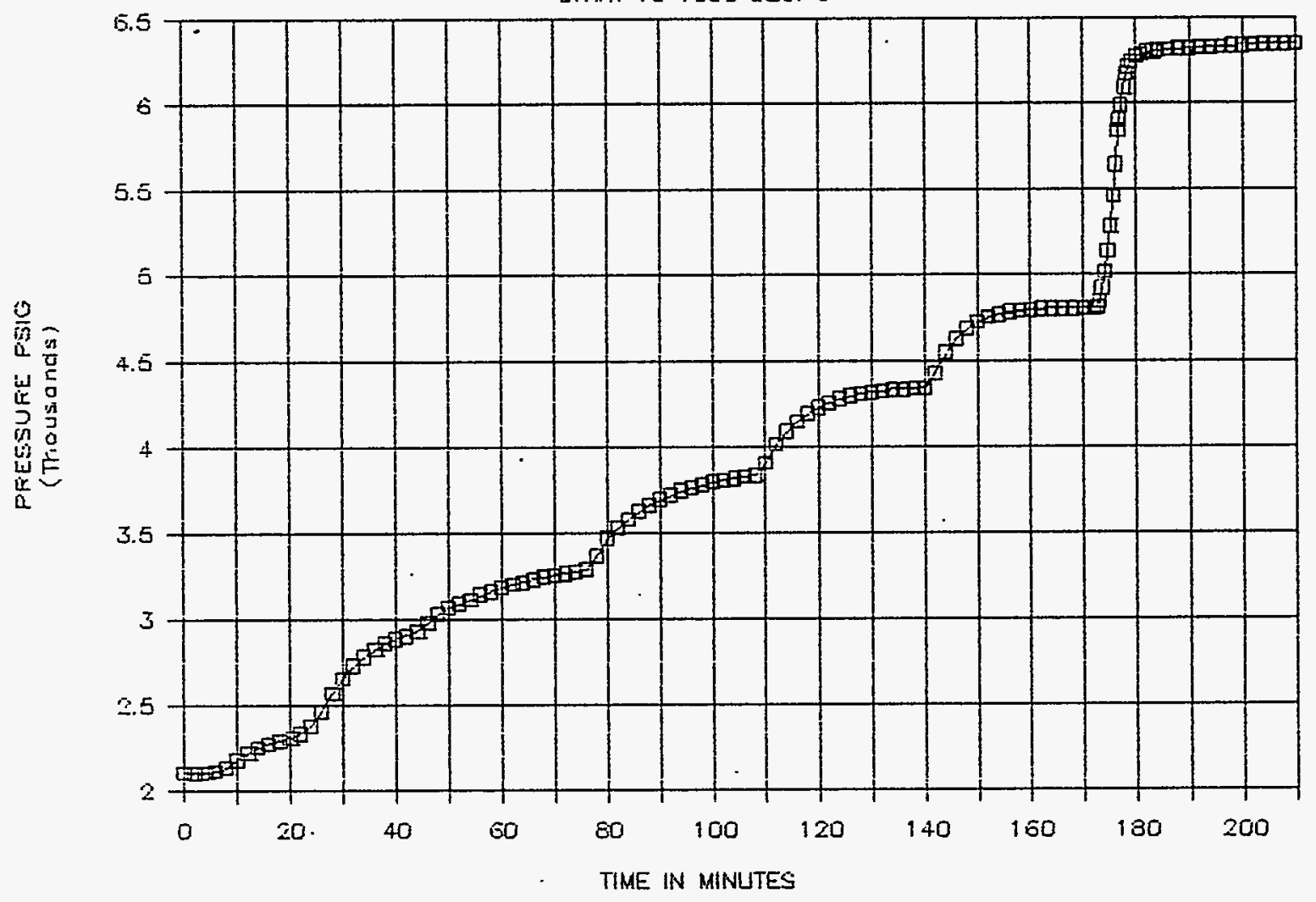

- PB8

FROM 40 HOIJRS TO FAILURE

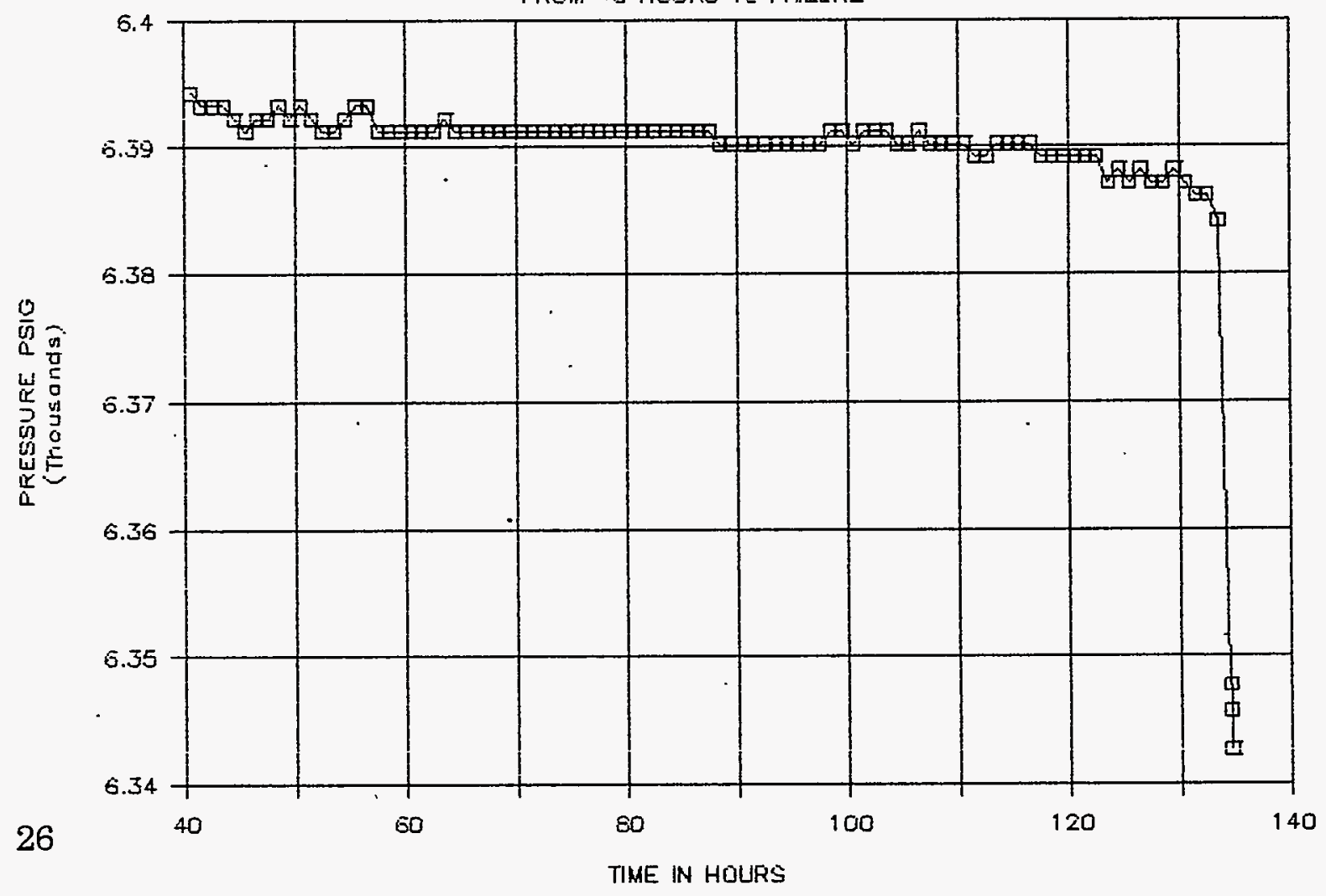




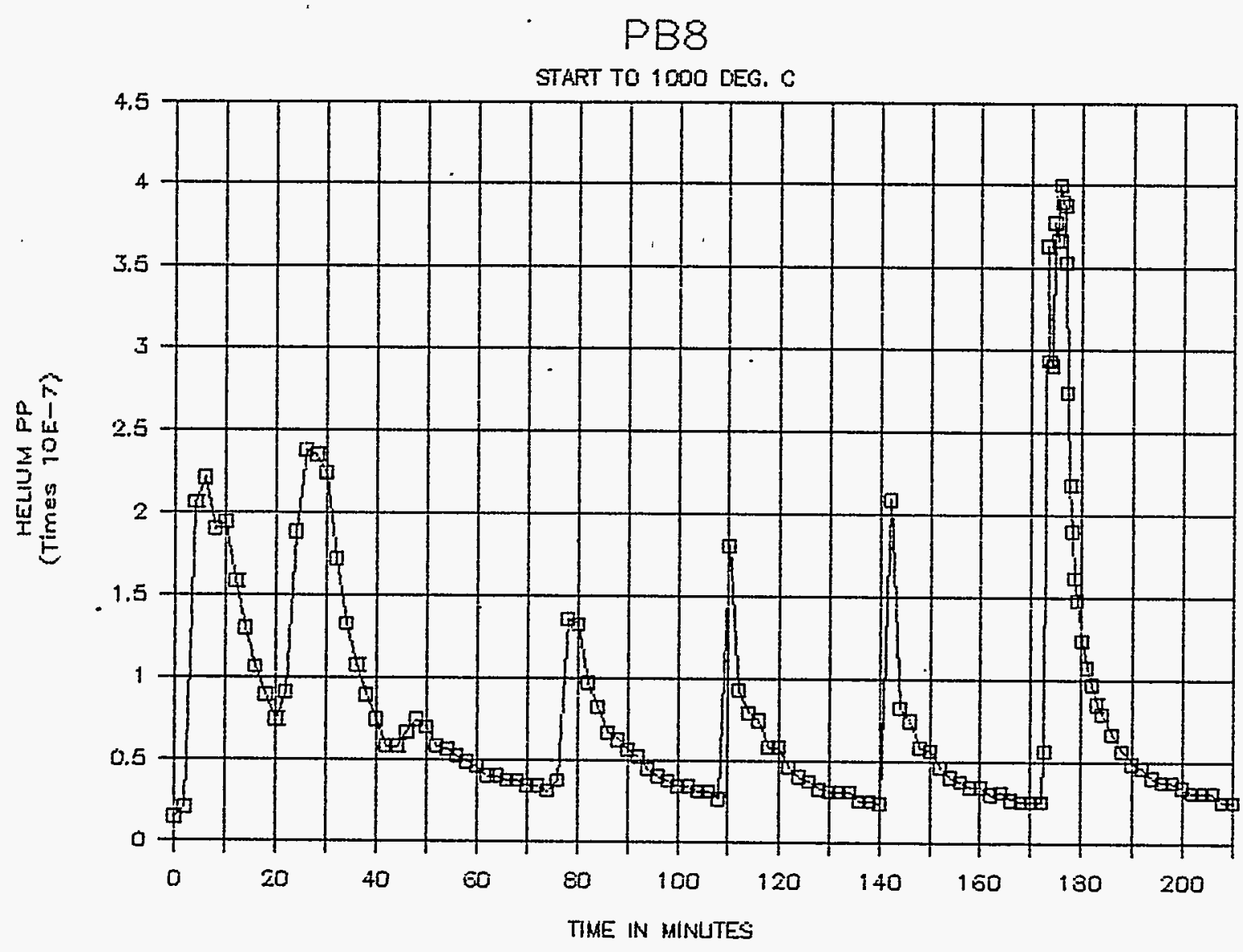

PB8

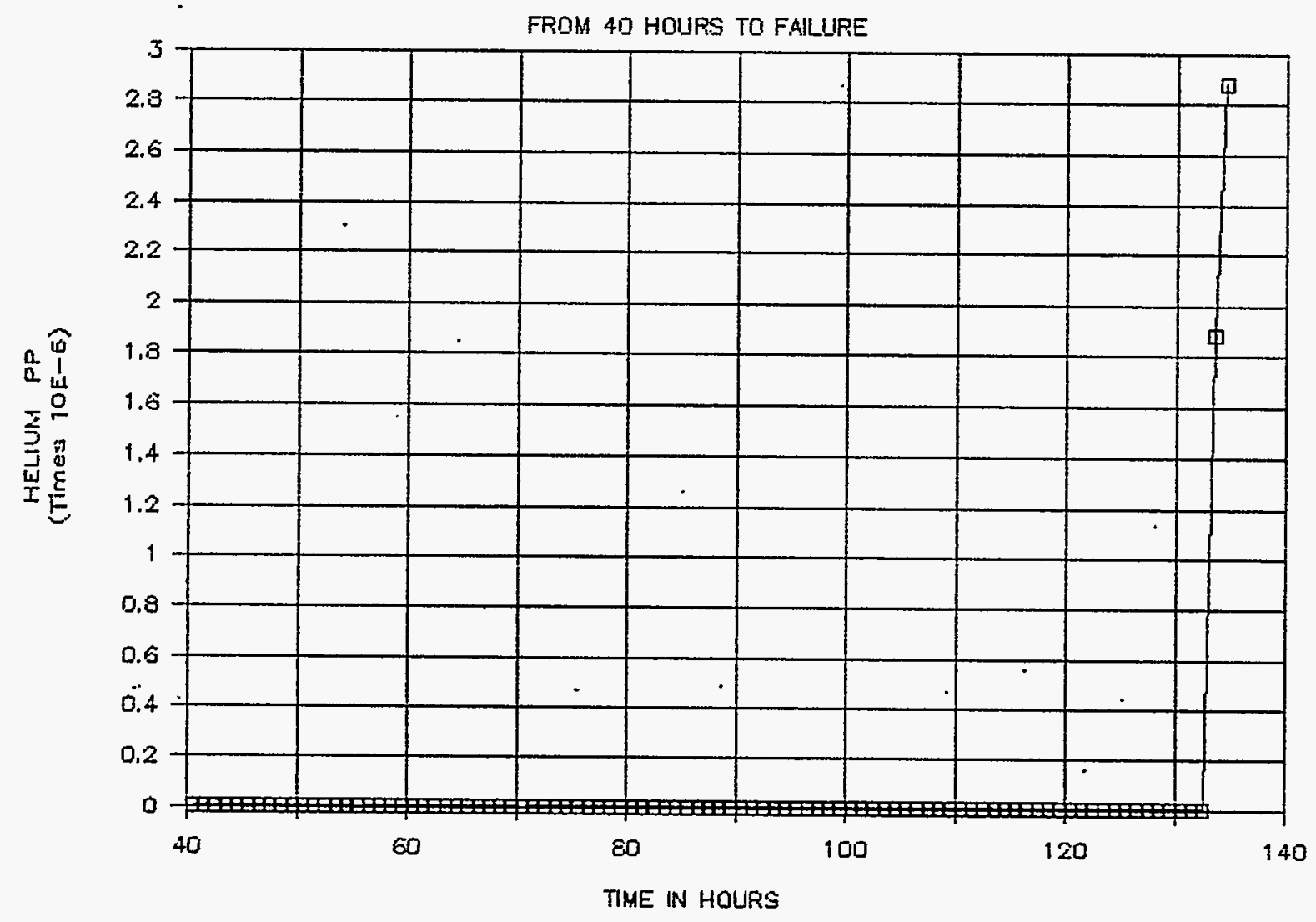


PB9

START TO 1000 DEG. C

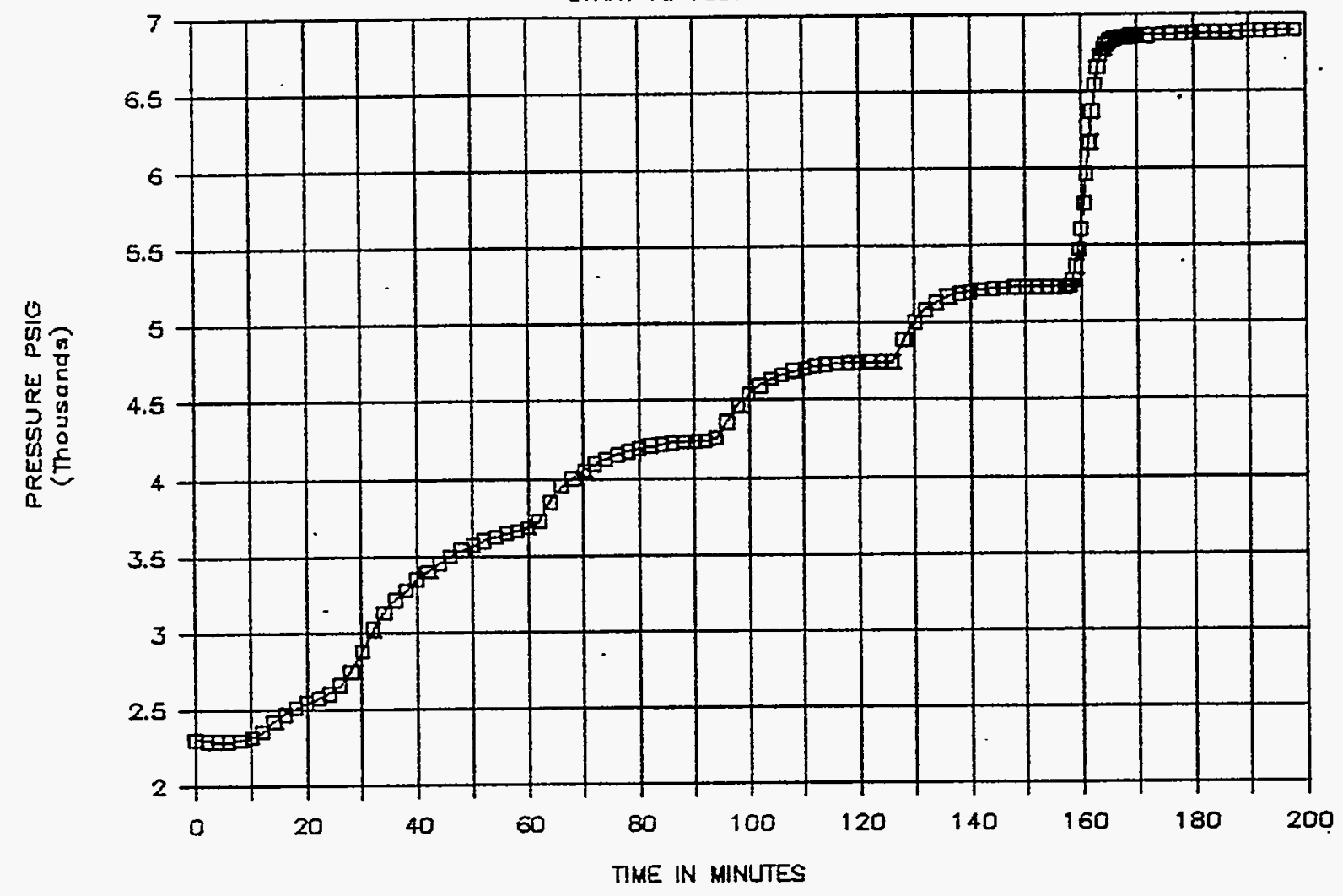

PB9

1000 DEG. C TO FAILURE

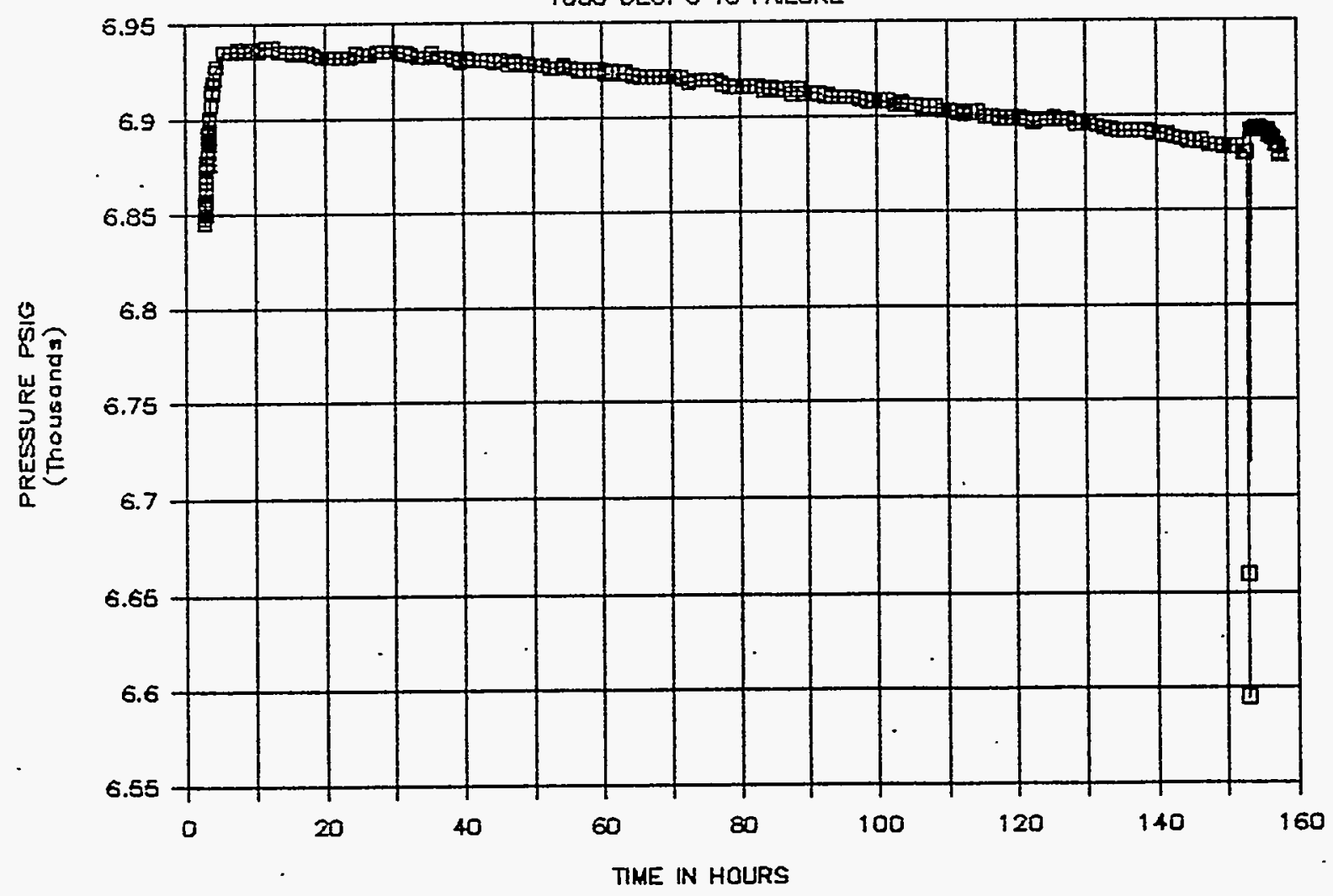




\section{PB9}

START TO 1000 DEG. C

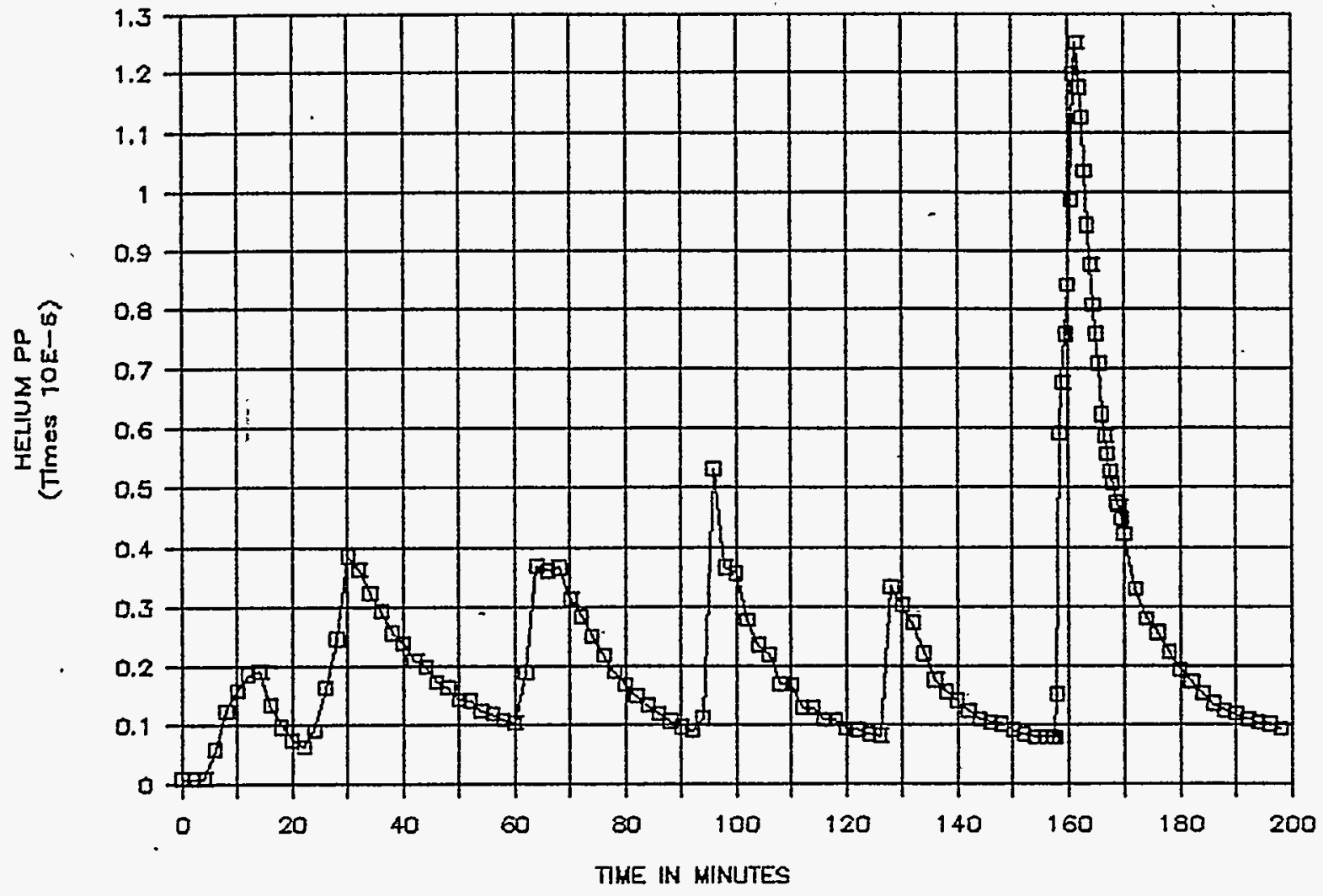

PB9

1000 DEG. C TO FAILURE

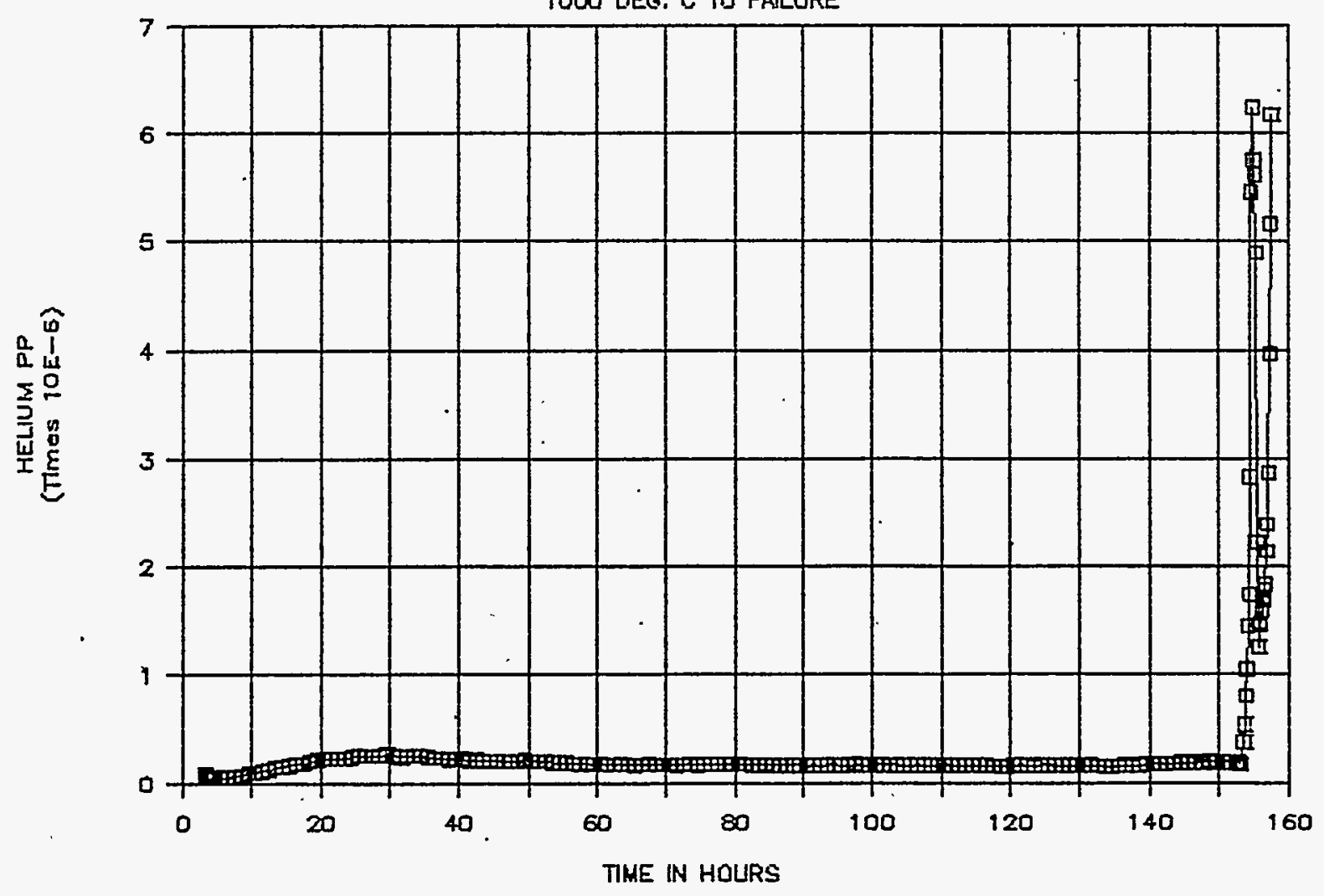




\section{Appendix B \\ Determination of Starting Gas Pressure}

The milliwatt capsule starting pressure was determined by the ideal gas equation $(\mathrm{PV}=\mathrm{mRT})$. The steps and assumptions are:

Starting conditions: $\mathrm{P}_{1} \mathrm{~V}_{1}=\mathrm{mRT}_{1}$

Maximum conditions : $\mathrm{P}_{2} \mathrm{~V}_{2}=\mathrm{mRT}_{2}$

Without leakage in the capsule the mass " $\mathrm{m}$ " is constant.

Rearranging the equations gives: $\mathrm{P}_{1} \mathrm{~V}_{1} / \mathrm{T}_{1}=\mathrm{P}_{2} \mathrm{~V}_{2} / \mathrm{T}_{2}$

Assumption: $V_{1}=V_{2}$ for small thermal expansion

Solving for pressure: $\mathrm{P}_{1}=\mathrm{P}_{2} \mathrm{~T}_{1} / \mathrm{T}_{2}$ or $\mathrm{P}_{2}=\mathrm{P}_{1} \mathrm{~T}_{2} / \mathrm{T}_{1}$

The 60-watt capsule test system is not the same as the milliwatt system. The milliwatt capsule/stem is sealed and placed in the hot zone of the furnace. This system does not allow measurement of the pressure, $\mathrm{P} 2$, at test temperature. The 60-watt system has the capsule attached to a tube that exits the furnace. The pressure, P2, is measured in the tube outside the furnace. The temperature of the gas whose pressure is being measured is not constant, but varies from test temperature to room temperature. The 60 -watt test conditions do not satisfy the ideal gas requirements.

The compression and expansion of a gas obey the equation $\mathrm{PV}^{\mathrm{n}}=\mathrm{C}$ fairly well, provided that the proper value is selected for the exponent $n$. The exponent $n$ may have many values $(-\infty$ to $+\infty)$. Any process obeying this law is called a polytropic process. The general relations are: $\mathrm{P}_{1} \mathrm{~V}_{1}{ }^{\mathrm{n}}=\mathrm{P}_{2} \mathrm{~V}_{2}{ }^{\mathrm{n}}$ 
By substituting the ideal gas equation into the polytropic equation, a relationship between temperature and pressure can be obtained. The following shows these steps:

$$
\begin{array}{lll}
\mathrm{P}_{1} \mathrm{~V}_{1}=\mathrm{mRT}_{1} & \text { and } & \mathrm{P}_{2} \mathrm{~V}_{2}=\mathrm{mRT}_{2} \\
\mathrm{~V}_{1}=\mathrm{mRT}_{1} / \mathrm{P}_{1} & \text { and } & \mathrm{V}_{2}=\mathrm{mRT}_{2} / \mathrm{P}_{2}
\end{array}
$$

Then substitute into: $P_{1} V_{1}{ }^{n}=P_{2} V_{2}{ }^{n}$

$$
\begin{array}{ll}
\mathrm{P}_{1}\left(\mathrm{mRT} \mathrm{T}_{1} / \mathrm{P}_{1}\right)^{\mathrm{n}} & =\mathrm{P}_{2}\left(\mathrm{mRT} \mathrm{T}_{2} / \mathrm{P}_{2}\right)^{\mathrm{n}} \\
\mathrm{P}_{1} \mathrm{~T}_{1}{ }^{\mathrm{n}} \mathrm{P}_{1}{ }^{-\mathrm{n}} & =\mathrm{P}_{2} \mathrm{~T}_{2}{ }^{\mathrm{n}} \mathrm{P}_{2}{ }^{-\mathrm{n}} \\
\left(\mathrm{P}_{1} / \mathrm{P}_{2}\right)^{\mathrm{x}} & =\mathrm{T}_{2} / \mathrm{T}_{1} \quad \text { where } \mathrm{x}=(1-\mathrm{n}) / \mathrm{n}
\end{array}
$$

The girth weld pressure burst test conditions were used in the comparison of the ideal gas equation and the polytropic equation. The starting pressure (P1) and the temperatures ( $\mathrm{T} 1$ and $\mathrm{T} 2$ ) were used to calculate the maximum pressure (P2) and the percent error from the actual maximum pressure. Table B-1 shows the ideal gas equation results and Table B-2 shows the polytropic equation results.

The ideal gas equation gave an average error of $46 \%$ in predicting P2, and this is not satisfactory. The polytropic equation has an average error of less than $3 \%$ for P2. In Table B-2 the second value for each temperature has less error than prior test. This is a result of using the information from the first test to calculatethe exponent for the second test at that temperature.

The test data from the girth weld capsules were used in a regression analysis to determine the exponent for the polytropic equation given the capsule volume $\left(\mathrm{V} \mathrm{cm}^{3}\right)$, test temperature $\left(\mathrm{T} 2{ }^{\circ} \mathrm{K}\right)$, and test pressure (P2 psia). The equation for the exponent is:

$$
\mathrm{n}=-6.0495 \mathrm{E}-02 \times \mathrm{V}-2.4681 \mathrm{E}-04 \times \mathrm{T} 2-5.5824 \mathrm{E}-05 \times \mathrm{P} 2
$$

Table B-3 shows the results using the exponent calculated from the regression analysis. 


\begin{tabular}{|c|c|c|c|c|c|}
\hline \multicolumn{6}{|c|}{ Table B-1 - PREDICTION OF P2 USING IDEAL GAS EQUATION } \\
\hline \multicolumn{3}{|c|}{ STARTING CONDITIONS } & \multirow{2}{*}{$\begin{array}{c}\text { TEST } \\
\text { P2 } \\
\text { PSIG }\end{array}$} & \multicolumn{2}{|c|}{ IDEAL GAS EQUATION } \\
\hline $\begin{array}{l}\mathrm{T} 1 \\
{ }^{\circ} \mathrm{C}\end{array}$ & $\begin{array}{l}\mathrm{T} 2 \\
{ }^{\circ} \mathrm{C}\end{array}$ & $\begin{array}{c}\text { P1 } \\
\text { PSIG }\end{array}$ & & $\begin{array}{c}\text { P2 } \\
\text { PSIG }\end{array}$ & $\begin{array}{c}\text { ERROR } \\
\text { PERCENT }\end{array}$ \\
\hline 20.2 & 1171 & 833 & 2907 & 4161 & 43.2 \\
\hline 18.9 & 1171 & 1083 & 3897 & 5417 & 39.0 \\
\hline 21.0 & 1260 & 750 & 2575 & 3974 & 54.3 \\
\hline 20.0 & 1260 & 1029 & 3555 & 5447 & 53.2 \\
\hline 20.0 & 1000 & 2104 & 6394 & 9191 & 43.8 \\
\hline 22.7 & 1000 & 2298 & 6937 & 9943 & 43.3 \\
\hline
\end{tabular}

\begin{tabular}{|c|c|c|c|c|c|}
\hline \multicolumn{6}{|c|}{ Table B-2 - PREDICTION OF P2 USING POLYTROPIC EQUATION } \\
\hline \multicolumn{3}{|c|}{ STARTING CONDITIONS } & \multirow{2}{*}{$\begin{array}{c}\text { TEST } \\
\text { P2 } \\
\text { PSIG }\end{array}$} & \multicolumn{2}{|c|}{ POLYTROPIC EQUATION } \\
\hline $\begin{array}{l}\mathrm{T} 1 \\
{ }^{\circ} \mathrm{C}\end{array}$ & $\begin{array}{l}\mathrm{T} 2 \\
{ }^{\circ} \mathrm{C}\end{array}$ & $\begin{array}{c}\text { P1 } \\
\text { PSIG }\end{array}$ & & $\begin{array}{c}\text { P2 } \\
\text { PSIG }\end{array}$ & $\begin{array}{c}\text { ERROR } \\
\text { PERCENT }\end{array}$ \\
\hline 20.2 & 1171 & 833 & 2907 & 2760 & -5.0 \\
\hline 18.9 & 1171 & 1083 & 3897 & 3780 & -3.0 \\
\hline 21.0 & 1260 & 750 & 2575 & 2732 & 6.1 \\
\hline 20.0 & 1260 & 1029 & 3555 & 3538 & -0.5 \\
\hline 20.0 & 1000 & 2104 & 6394 & 6297 & -1.5 \\
\hline 22.7 & 1000 & 2298 & 6937 & 6933 & -0.1 \\
\hline
\end{tabular}

\begin{tabular}{|c|c|c|c|c|}
\hline \multicolumn{2}{|c|}{ EXPONENT $n$} & \multirow{2}{*}{$\begin{array}{c}\begin{array}{c}\text { TEST } \\
\text { P2 }\end{array} \\
2922 \text { psia }\end{array}$} & \multirow{2}{*}{$\begin{array}{c}\begin{array}{c}\text { REGRESSION } \\
\text { P2 }\end{array} \\
2885 \text { psia }\end{array}$} & \multirow{2}{*}{$\begin{array}{c}\begin{array}{c}\text { EXPONENT } \\
\text { ERROR }\end{array} \\
-1.25 \%\end{array}$} \\
\hline-2.9012 & -3.311 & & & \\
\hline-3.4578 & -3.954 & 3912 psia & 3934 psia & $+0.56 \%$ \\
\hline-3.4269 & -2.884 & 2590 psia & 2601 psia & +0.41 \\
\hline-2.8476 & -2.939 & 3570 psia & 3589 psia & +0.53 \\
\hline$-2.8918^{\circ}$ & -3.033 & 6409 psia & 6396 psia & -0.20 \\
\hline-3.0562 & -3.063 & 6952 psia & 6953 psia & +0.01 \\
\hline
\end{tabular}




\section{Stress Equations for End Cap Weld Design}

The tangential stresses at the intersection of the cylinder wall and the end cap are the sum of the following:

1. Hoop stress in a thin wall cylinder

$$
\begin{aligned}
\mathrm{SC} & =(\mathrm{P} * \mathrm{r}) / \mathrm{t} \\
\text { where } \mathrm{P} & =\text { internal pressure }(\mathrm{psi}) \\
\mathrm{r} & =\text { inside radius } \\
\mathrm{t} & =\text { wall thickness }
\end{aligned}
$$

2. Tangential stress in a flat plate fixed at edge

$$
\mathrm{SP}=[(3 * \mathrm{~W}) /(8 * 3.1416 * \mathrm{~m} * \mathrm{t})] *\left[(\mathrm{~m}+3)\left(\mathrm{r}^{2} / \mathrm{a}^{2}\right)-(\mathrm{m}+1)\right]
$$

where $\mathrm{W}=$ total force on cap

$\mathrm{m}=$ inverse of Poisson's ratio

a $=$ inside radius

$r$ = distance from center (for this case $r=a$ ) 


\section{Distribution}

EXTERNAL

OSTI, UC-704 (103)

W. R. Amos, DOE/MB

S. T. Christenbury, Teledyne Brown Engineering

D. V. Eckman, DOE/MB

T. A. Frazier, DOE/MB

J. Hales, DOE/NE-53

INTERNAL

W. A. Bohne

C. D. Barkley

J. L. Fisher

E. N. Fray

D. M. Gabriel

E. I. Howell

F. A. Koehler

J. R. McDougal

R. McNeese

J. D. Ruhkamp (5)

L. A. Sowders

G. S. West

Editor, Mary J. Pacinda

Technical Publications 


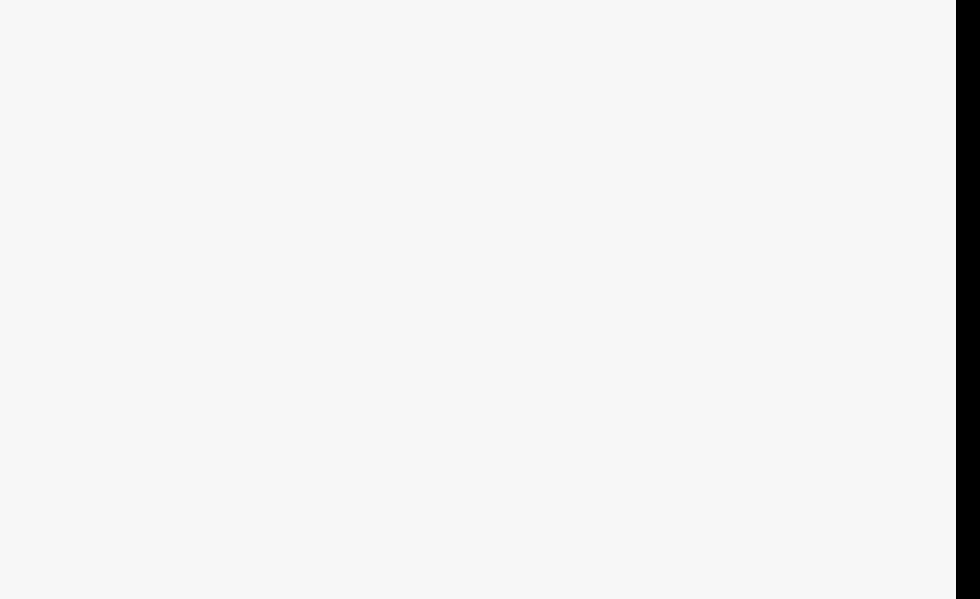

